\title{
LA PROTECCIÓN DE LOS MENORES FRENTE AL ABUSO Y LA EXPLOTACIÓN SEXUAL A TRAVÉS DE LAS CONSECUENCIAS JURÍDICAS DEL DELITO APLICABLES A LAS PERSONAS FÍSICAS IMPUTABLES
}

\author{
María Marta GonZÁlez Tascón \\ Profesora Titular de Derecho Penal \\ Universidad de Oviedo
}

SUMARIO: I. Contextualización. II. La intensificación del uso de la pena de prisión y el endurecimiento de su cumplimiento. III. Las penas privativas de derechos conectados con la función protectora de los menores: 1. Observaciones previas. 2. La pena de privación de la patria potestad. 3. La pena de inhabilitación especial para el ejercicio de los derechos de la patria potestad, tutela, curatela, guarda o acogimiento. 4. Breve apunte sobre su ejecución. IV. Las penas de inhabilitación especial para empleo o cargo público o ejercicio de la profesión u oficio y para cualquier profesión u oficio que conlleve contacto con menores de edad. V. Las penas de alejamiento. VI. La medida de seguridad de libertad vigilada. VII. La toma de muestras biológicas del condenado para la obtención de identificadores de ADN y su inscripción en la base de datos policial. VIII. La restricción del ejercicio de profesiones o actividades que impliquen contacto habitual con menores. IX. El Registro Central de Delincuentes Sexuales.

Resumen: En este trabajo se realiza un estudio de las consecuencias jurídicas que la legislación española enlaza a los delitos sexuales con víctimas menores de edad incidiendo en particular en los problemas jurídicos que las mismas plantean.

Palabras claves: víctimas menores de edad, delitos sexuales, sanciones penales, consecuencias del delito

\section{Contextualización}

El estatuto jurídico de las personas menores de edad comenzó a cambiar, como es bien sabido, de forma radical a finales del siglo XX a raíz 
de su reconocimiento constitucional e internacional como auténticos titulares de derechos. No obstante, son muchas las situaciones en las que, debido a la realidad biológica, psicológica y social de la infancia y de la adolescencia, el ordenamiento jurídico debe dispensar a la persona menor de edad una protección especial o reforzada para garantizar su bienestar y desarrollo; incluso aun cuando ello pudiera suponer limitaciones al ejercicio personal de su derechos. Entre estas situaciones se encontraría su involucración en actos de naturaleza sexual a causa de interferencias de terceros que suponen un peligro o dañan su desarrollo personal en la esfera sexual o afectan, en su caso, a su libertad sexual ${ }^{1}$. Unas conductas abusivas de las que, dependiendo no obstante también de otros factores de distinta naturaleza y de la forma en la que éstos se interrelacionan con aquellas, se pueden irradiar para esos menores daños de índole diversa, así emocionales, sociales, de conducta y físicos, tanto a corto como a largo plazo ${ }^{2}$.

El problema del abuso y la explotación sexual de los menores de edad no logró irrumpir con fuerza en la agenda política, tanto en el plano internacional como a nivel interno en España, hasta hace pocas décadas; manteniéndose, eso sí, desde entonces en ella como algo prioritario para la salvaguarda de los derechos de los niños. Esto ha hecho que en el momento presente sea fácilmente reconocible la existencia de una auténtica política internacional contra esta lacra que se ha ido plasmando no sólo a través de numerosas recomendaciones, directrices o pautas de actuación elaboradas por organismos internacionales gubernamentales, sino también en auténticas normas jurídicas vinculantes para España, condicionantes del tratamiento de la cuestión a nivel nacional. Una política criminal que se fundamentaría en tres grandes pilares: el tradicional de la persecución criminal (especialmente dirigida a impulsar la cooperación a nivel policial y judicial entre los Estados y la aproximación de las legislaciones nacionales en la tipificación y el castigo de las conductas merecedoras de relevancia penal con el fin de superar problemas jurisdiccionales y las diferencias jurídico valorativas de los hechos, que difi-

1 *Este trabajo se enmarca dentro del Proyecto DER2015-63669-R, "Un sistema de sanciones penales para el siglo XXI", dirigido por el Prof. Luis Roca de Agapito, y del Proyecto emergente GV/2019/061, "La victimización del menor y la relevancia de su consentimiento en los delitos contra la indemnidad sexual y la intimidad", dirigido por la Profa. Mar Moya Fuentes.

Nótese que existe un debate sobre el bien jurídico protegido en los delitos sexuales con víctimas menores de edad a las que se niega la capacidad de consentir legalmente actos sexuales; apelando unos a su indemnidad sexual y manteniendo otros la referencia a su libertad sexual.

2 Cantón-Cortés, D./ Cortés, M. R., «Consecuencias del abuso sexual infantil: una revisión de las variables intervinientes», en Anales de Psicología, 2015, vol. 31, nº. 2, p. 559. Un cuadro resumen de las consecuencias del abuso puede consultarse en Benavente, B./ Casado, S./ Orte, C./ Ballester, L., Prevalencia del abuso sexual en la infancia. Un estudio en estudiantes universitarios, Ed. Octaedro, Barcelona, 2016, pp. 29-34. 
cultan la investigación y la persecución del delito y, consiguientemente, favorecen a los delincuentes), el habitualmente más desatendido de la protección de las víctimas mediante la adopción de medidas dirigidas a articular servicios de ayuda y asistencia a las mismas y el de la prevención de estos delitos a todos los niveles.

A lo largo de estas líneas nosotros vamos a centrar nuestra atención únicamente en la cuestión relativa a las consecuencias jurídicas que la legislación española enlaza a los delitos sexuales en perjuicio de menores o con víctimas menores de edad en tanto que instrumentos de prevención de estos delitos y, consiguientemente, de protección de los menores. A tal fin, y considerando la amplitud del tema, vamos a orientar nuestra mirada hacia aquellas consecuencias jurídicas que estando destinadas a las personas físicas responsables penalmente bien presentan una naturaleza penal o bien han sido incorporadas en nuestra legislación en fechas recientes ${ }^{3}$.

Antes de adentrarnos en la cuestión, y dado que es frecuente que nuestro legislador justifique las reformas del tratamiento de esta problemática en el cumplimiento de la normativa supranacional, aprovecharemos este epígrafe introductorio para dejar constancia de la atención que a las consecuencias jurídicas del delito se presta en la normativa internacional de referencia en materia de abuso y explotación sexual de menores. Ello servirá también para que se pueda comprobar si el legislador nacional adapta nuestra legislación a las exigencias del derecho supranacional o se sirve sencillamente de éste para apuntalar una política criminal de intensificación de la respuesta frente a los delincuentes sexuales cuyas víctimas son menores de edad.

El Convenio sobre los derechos del niño, de 20 de noviembre de 1989 (en adelante $\mathrm{CDN}$ ), de forma comprensible a tenor de su finalidad, se limita a apelar a la adopción por los Estados de medidas legislativas, administrativas, sociales y educativas apropiadas para proteger al niño ${ }^{4}$. Su

${ }^{3}$ Las personas jurídicas también pueden ser responsables penalmente de los delitos relativos a la explotación sexual de menores (art. 189 bis) y del delito de trata de seres humanos, una de cuyas finalidades puede ser la explotación sexual de las personas (art. 177 bis 7$)$.

${ }^{4}$ Artículo 19.1: "Los Estados Partes adoptarán todas las medidas legislativas, administrativas, sociales y educativas apropiadas para proteger al niño contra toda forma de perjuicio o abuso físico o mental, descuido o trato negligente, malos tratos o explotación, incluido el abuso sexual, mientras el niño se encuentre bajo la custodia de los padres, de un representante legal o de cualquier otra persona que lo tenga a su cargo. 2. Esas medidas de protección deberían comprender, según corresponda, procedimientos eficaces para el establecimiento de programas sociales con objeto de proporcionar la asistencia necesaria al niño y a quienes cuidan de él, así como para otras formas de prevención y para la identificación, notificación, remisión a una institución, investigación, tratamiento y observación ulterior de los casos antes descritos de malos tratos al niño y, según corresponda, la intervención judicial". Y artículo 34: "los Estados Partes se comprometen a proteger al niño contra todas las formas de explotación y abuso sexuales. Con este fin, los 
Protocolo facultativo relativo a la venta de niños, la prostitución infantil y la utilización de los niños en la pornografía, de 25 de mayo de 2000 , que ya incide en la tipificación de hechos concretos, no fue más allá de determinar que los mismos fuesen castigados con penas adecuadas a su gravedad (art. 3.3) y de disponer, si bien con sujeción a las disposiciones nacionales, la adopción de medidas de incautación y confiscación de los bienes, activos y medios utilizados para cometer o facilitar la comisión de los delitos y de las utilidades obtenidas de éstos así como de medidas de cierre, temporal o definitivo, de los locales utilizados para cometer los delitos (art. 7).

El interés por las consecuencias jurídicas de estos delitos cobra protagonismo en el ámbito regional del Consejo de Europa y de la Unión Europea (UE) ${ }^{5}$, donde se han aprobado, respectivamente, el Convenio del Consejo de Europa para la protección de los niños contra la explotación y el abuso sexual, de 25 de octubre de 2007 (Convenio de Lanzarote), y la Directiva del Parlamento Europeo y del Consejo 2011/93/UE relativa a la lucha contra los abusos sexuales y la explotación sexual de los menores y la pornografía infantil y por la que se sustituye la Decisión marco

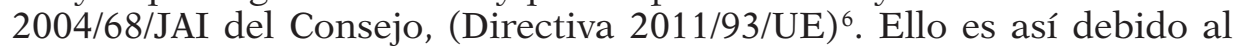
marcado enfoque victimocéntrico de ambas normas, que ha supuesto una mayor atención a la prevención del delito y a la protección de estas víctimas; consideración que se otorga en el Convenio de Lanzarote a quienes son víctimas de las conductas descritas bajo los enunciados abuso sexual, delitos relativos a la prostitución infantil, delitos relativos a la pornografía infantil, delitos relativos a la participación de niños en espectáculos pornográficos, corrupción de niños y proposiciones a niños con fines sexuales a través de las TIC (arts. 3.c y 18 a 23) y en la Directiva 2011/93/UE a las infracciones relacionadas con los abusos sexuales, infracciones relacionadas con la explotación sexual, infracciones relacionadas con la pornografía infantil y el embaucamiento de menores con

Estados Partes tomarán, en particular, todas las medidas de carácter nacional, bilateral y multilateral que sean necesarias para impedir: a) la incitación o la coacción para que un niño se dedique a cualquier actividad sexual ilegal; b) la explotación del niño en la prostitución u otras prácticas sexuales ilegales; c) la explotación del niño en espectáculos o materiales pornográficos".

5 En el Consejo de Europa también se aprobó el Convenio sobre ciberdelincuencia, de 23 de noviembre de 2001, que ordenaba la tipificación de delitos relacionados con la pornografía infantil (art. 9) y apelaba a la aplicación de sanciones efectivas, proporcionadas y disuasorias, incluidas penas privativas de libertad (art. 13.1).

6 Vid. Salat Paisal, M., «Las consecuencias sancionadoras aplicables a los delincuentes sexuales tras las últimas reformas legislativas», en $E P C, 2016$, vol. XXXVI, pp. 286-299; quien además, en pp. 299-320, nos explica cómo se cumplen en otros países de la UE las medidas previstas en esas normas. También sobre el tema este mismo autor en «Sanciones penales en los delitos sexuales contra menores», en Tamarit Sumalla, J. M., (coord.), La victimización sexual de menores de edad y la respuesta del sistema de justicia penal, Ed. Edisofer, Madrid, 2017, pp. 247-260. 
fines sexuales por medios tecnológicos (arts. 3 a 6$)^{7}$. Conductas en gran parte coincidentes entre sí, pero que no reflejan la totalidad de los delitos sexuales de los que puede ser víctima un menor de edad con arreglo al título VIII del CP (así los delitos de exhibicionismo y provocación sexual o el acoso sexual).

El Convenio de Lanzarote recoge en su capítulo VI, dedicado al Derecho penal sustantivo, un artículo específicamente rubricado sanciones y medidas, en el que se ordena la adopción de las medidas legislativas o de otro tipo para que los delitos allí descritos sean punibles con sanciones efectivas, proporcionadas y disuasorias, habida cuenta de su gravedad, entre las que necesariamente han de incluirse penas privativas de libertad que puedan dar lugar a la extradición del delincuente (art. 27.1) ${ }^{8}$. Esta última precisión significaría en el momento presente, si consideramos la normativa en materia de detención y entrega de los delincuentes, que esa pena privativa de libertad susceptible de ser impuesta tiene que tener una duración máxima de al menos un año, y así se dice en el Informe Explicativo del Convenio de Lanzarote (§ 182), apelando en concreto al artículo 2 del Convenio europeo sobre extradición, de 13 de diciembre de $1957^{9}$. Más allá de esta concreción el Convenio de Lanzarote no impone el recurso a ninguna otra pena específica.

Sin prejuzgar su naturaleza jurídica, el Convenio de Lanzarote establece la obligación o la facultad de los Estados Parte de adoptar medidas legislativas o de otro tipo ${ }^{10}$. Se estipulan, de forma imperativa, el embargo y decomiso de los bienes, documentos y otros instrumentos utiliza-

7 Vid. entre otros, González Tascón, M. M., «La protección penal de los menores en la esfera sexual a la luz del Convenio del Consejo de Europa para la protección de los niños contra la explotación y el abuso sexual», en RDPCrUNED, 2012, n' .8 , pp. 91-96; y «Nuevas obligaciones para España en la lucha contra la explotación sexual de los menores y la pornografía infantil: la Directiva 2011/92/UE», en $R P, 2012, n^{\circ} .30$, pp. 48-52.

8 El apartado 2 del artículo 27 se refiere específicamente a las consecuencias de estos delitos para las personas jurídicas declaradas responsables de los mismos.

9 En el mismo sentido el Convenio de 27 de septiembre de 1996, establecido sobre la base del artículo K. 3 del Tratado de la UE relativo a la extradición entre los Estados miembros de la UE (art. 2.1). En relación con la orden de detención y entrega, aplicada dentro de la UE, la Ley 23/2014, de 20 de noviembre, de reconocimiento mutuo de resoluciones penales en la UE, establece en el caso de los delitos relativos a la explotación sexual de menores y pornografía infantil sin control de la doble tipificación que el hecho esté castigado en el país de emisión con una pena privativa de libertad de duración máxima de al menos tres años (art. 47.1). Fuera de este caso, el hecho tiene que estar castigado en la legislación del Estado emisor de la euroorden con una pena privativa de libertad de duración máxima de al menos doce meses (art. 47.2). La Ley 4/1985, de 21 de marzo, de extradición pasiva, dispone que España podrá conceder la extradición por hechos castigados con pena de privación de libertad de duración no inferior a un año en su grado máximo (art. 2.1).

${ }^{10}$ La redacción del artículo 27 y la conclusión del Informe explicativo del Convenio de Lanzarote en relación en particular con las medidas contenidas en el artículo 27.3 (§. 189) ponen de manifiesto que no se pronuncian sobre la naturaleza jurídica. 
dos para cometer o facilitar la comisión de esos delitos y del producto de éstos o de bienes de valor equivalente a éste (art. 27.3.a) ${ }^{11}$, el cierre temporal o definitivo de todo establecimiento utilizado para cometer el delito (art. $27.3 \mathrm{~b}$ primer inciso) o la denegación al autor, con carácter temporal o definitivo, del ejercicio de la actividad profesional o benéfica que conlleve el contacto con niños y con ocasión de la cual se haya cometido el delito" (art. 27.3 b in fine); medida esta última que se presenta para los Estados como una alternativa al cierre temporal o definitivo de los establecimientos ${ }^{12}$. La mención a la posibilidad de adoptar otras medidas se realiza de forma genérica, poniéndose como ejemplo de ellas la retirada de la patria potestad o el control o supervisión de las personas condenadas (art. 27.4) ${ }^{13}$. Igualmente se dispone que se adopten las medidas necesarias para que en la determinación de la pena sea posible tener en cuenta las condenas por estos delitos dictadas en otro Estado Parte $\left(\right.$ art. 29) ${ }^{14}$.

Algunas de las finalidades a las que sirven estas consecuencias del delito se encauzan también a través de su estrategia de prevención primaria. Así, podemos observar que el objetivo de prevención especial que se busca con la prohibición prevista en el artículo 27.3 b in fine está presente igualmente en la obligación de adoptar "medidas legislativas o de otro tipo necesarias para que las condiciones de acceso a las profesiones cuyo ejercicio conlleve el contacto habitual con niños garanticen que los aspirantes a ejercer dichas profesiones no hayan sido condenados por actos de explotación o abuso sexual de niños" (art. 5.3). Como estas últimas se han de establecer de conformidad con el derecho interno, el Informe explicativo del Convenio de Lanzarote señala que los Estados Partes han de implementarlas de forma compatible con sus normas internas, muy en particular, las relativas a la reeducación y reinserción social de los penados; incidiendo además ese informe en el hecho de que la misma no persigue interferir en las legislaciones nacionales que prevean la cancelación de los antecedentes penales después del transcurso de un plazo de tiempo (§57).

11 El artículo 27.5 contempla la posibilidad de que el producto del delito y los bienes decomisados se asignen a un fondo especial destinado a la financiación de los programas de prevención y asistencia a las víctimas de estos delitos.

12 Igualmente el Informe explicativo del Convenio de Lanzarote (§ 187).

13 La retirada de la patria potestad, según el Informe explicativo del Convenio de Lanzarote (§ 191), podría ser acordada, por ejemplo, en relación a quien previamente fue objeto de una medida de asistencia en favor de la víctima que implicaba el alejamiento del ámbito familiar. La supervisión, según se señala en el Informe explicativo del Convenio de Lanzarote (§ 192), debería ser tomada en aras, por ejemplo, de facilitar la valoración del riesgo de reincidencia o de garantizar la eficacia de los programas y medidas de tratamiento; y podría ser adoptada en relación tanto a personas que cumplen penas o en su lugar están sometidas a medidas de prueba como a personas que ya han cumplido la pena.

${ }_{14}$ Se contempla como circunstancia agravante que el autor haya sido condenado anteriormente por delitos de la misma naturaleza (art. $28 \mathrm{~g}$ ). 
Entre la prohibición inicialmente mencionada y esta condición es posible, no obstante, apreciar importantes diferencias. La primera afecta al ejercicio tanto de la actividad profesional como de la actividad benéfica que conlleve el contacto con niños, pero sólo cuando el delito se ha cometido con ocasión de su ejercicio. La segunda, en cambio, se circunscribe a la restricción de la actividad profesional ${ }^{15}$. Además incide únicamente en el acceso a esa actividad, lo que significa que si bien en ocasiones impedirá también su ejercicio, no sucederá así cuando la persona ya se hallaba desempeñando ese tipo de actividad profesional. Debe resaltarse asimismo que no es necesario para que opere la condición que la persona condenada por delitos sexuales en perjuicio de menores haya cometido éstos en el ejercicio de la actividad. E igualmente hay que tener presente que mientras la primera puede ser temporal o definitiva, la segunda podría ser únicamente temporal, dependiendo de la legislación de los Estados.

En el artículo 37.1 del Convenio de Lanzarote se señala otra medida preventiva, novedosa e imperativa, que se deriva de la comisión de estos delitos. Se trata de la recogida y el almacenamiento de los datos relativos a la identidad y el perfil genético (ADN) de las personas condenadas por estos delitos mediante la que se persigue alcanzar una mayor eficacia en la prevención y el enjuiciamiento de los delitos. No obstante, posiblemente considerando los derechos afectados por este tipo de medida, se expresa en esa norma que su adopción ha de realizarse conforme con las disposiciones aplicables sobre protección de datos de carácter personal y otras normas y garantías apropiadas que el derecho interno.

La Directiva 2011/93/UE ha incidido también, como apuntábamos, sobre las consecuencias jurídicas de los delitos sexuales con víctimas menores de edad, señalando penas y otras sanciones o medidas cuya naturaleza no se precisa. Por lo que se refiere a la persona física responsable de estos delitos ${ }^{16}$, salvo en una concreta infracción en la que no se especifica por tratarse en realidad de una tentativa de algunas modalidades de los delitos relacionados con la pornografía infantil (art. 6.2), se impone la pena privativa de libertad, con la novedad de que se señala un límite máximo de duración por referencia a una concreta duración mínima para cada una de las infracciones penales que allí se contemplan $(\text { arts. } 3 \text { a } 6.1)^{17}$.

15 En el Informe explicativo del Convenio de Lanzarote, se menciona que en ciertos estados esta obligación también puede ser aplicada a las actividades de voluntariado ( $§$ 57).

16 El artículo 13 está destinado propiamente a las sanciones para las personas jurídicas.

17 En las infracciones que tienen menor pena de prisión el límite máximo de duración de ésta es de al menos uno año mientras que en el delito más grave se prevé una duración máxima de al menos diez años. 
En su artículo 10, bajo el enunciado "inhabilitación derivada de las sentencias condenatorias", se dispone la adopción por parte de los Estados miembros de las siguientes medidas. En primer lugar, resulta imperativa para éstos, en aras de evitar la reincidencia ${ }^{18}$, la adopción de medidas que garanticen que una persona condenada por estos delitos, pueda ser inhabilitada, con carácter temporal o permanente ${ }^{19}$, para el ejercicio de actividades, al menos profesionales, que impliquen contactos directos y regulares con menores (art. 10.1) ${ }^{20}$. A tenor de esta disposición, este tipo de inhabilitación, sea cual sea su naturaleza jurídica, tiene que contemplarse en la ley nacional, pero no necesariamente ha de aplicarse imperativamente por ley. Si consideramos, por otra parte, que el riesgo de reincidencia es lo que marcaría su aplicación, lo que parece más lógico en atención a nuestro concreto sistema jurídico es que esta medida se adopte en la jurisdicción penal, lo que no significa que estemos prejuzgando su naturaleza penal, dado que si la ley así lo dispone los jueces del orden penal puede aplicar medidas no penales.

En segundo lugar, el artículo 10.2 exige a los Estados miembros la adopción de las medidas necesarias para garantizar que los empresarios tengan derecho a solicitar información sobre la existencia de condenas por los delitos de referencia que conste en el registro de antecedentes penales o sobre cualquier inhabilitación para ejercer actividades que impliquen contactos directos y regulares con menores derivada de dichas condenas penales, con motivo de la contratación de una persona para realizar actividades profesionales o actividades de voluntariado organizadas que impliquen contactos directos y regulares con menores. Este derecho se ejercerá de conformidad con el derecho nacional, no estando en la voluntad de la directiva la modificación de los regímenes nacionales aplicables a los registros de antecedentes penales o a las vías de acceso a su contenido (considerando 41 de la Directiva 2011/93/UE). Así las cosas, se menciona en el artículo 10.2, a mero título de ejemplo sobre los

18 Las condenas anteriores por estos delitos se prevén también como una circunstancia agravante del delito (art. 9 c).

19 Salat Paisal, M., «Las consecuencias sancionadoras aplicables a los delincuentes sexuales tras las últimas reformas legislativas», cit., p. 289, plantea una interpretación restrictiva de este precepto en el sentido de abogar por entender que la directiva no obliga a que los Estados contemplen la inhabilitación con ese doble carácter, de forma que sería factible que aquellos sólo le atribuyesen un carácter temporal. Ciertamente esta posibilidad armonizaría en mayor medida con la idea resocializadora de las penas ligada también a la dignidad humana, sin embargo, la dicción del precepto admite también otra lectura conforme a la cual tendría que articularse como pena temporal y como pena permanente, siendo el órgano judicial, quien en atención a la gravedad de los hechos adoptaría la decisión procedente. Esta lectura se ve refrendada en el considerando 40 de la Directiva, donde se puede leer "con carácter temporal o permanente, en caso necesario".

20 Obsérvese que el Convenio de Lanzarote habla de un contacto habitual. 
medios apropiados para ejercer ese derecho, el acceso previa petición o a través del interesado ${ }^{21}$.

El tenor de este artículo, muy diferente del ya referido artículo 5.3 del Convenio de Lanzarote, no permitiría afirmar que la Directiva 2011/93/ UE establezca una obligación para los Estados de condicionar el acceso a determinadas actividades profesionales o de voluntariado a la inexistencia de condenas por los delitos de referencia que conste en el registro de antecedentes penales o de inhabilitación para ejercer actividades que impliquen contactos directos y regulares con menores derivada de esas condenas penales, pues lo que se está recogiendo ahí realmente es un derecho del empresario a recibir determinada información que no lleva aparejado un deber correlativo de no contar con la persona que ha recibido tal condena o inhabilitación ${ }^{22}$, pero el sentido al que respondería la norma es el primero. Téngase igualmente presente que este derecho a recibir determinada información se reconoce tanto en la organización de las actividades profesionales como en las actividades de voluntariado siempre que ambas impliquen contactos directos y regulares con menores. De ahí que en el considerando 40 de la Directiva 2011/93/UE se aclare que la noción de empresario "también debe abarcar a las personas que estén al frente de una organización dedicada a labores de voluntariado que guarden relación con la vigilancia o el cuidado de menores y que impliquen contactos directos y regulares con ellos".

En aras de que estas previsiones tengan eficacia en todo el territorio de la UE se contempla en el apartado 3 del artículo 10 que los Estados miembros adopten las medidas necesarias para que la información relativa a la existencia de esas condenas penales o esa inhabilitación sea transmitida con arreglo a los procedimientos establecidos en la Decisión marco 2009/315/JAI del Consejo, de 26 de febrero, relativa a la organización y al contenido del intercambio de información de los registros de antecedentes penales entre los Estados miembros.

Finalmente en el artículo 11 se refiere la Directiva 2011/93/UE a la adopción de las medidas necesarias para el embargo y al decomiso de los instrumentos y productos de estos delitos salvo en el caso del delito de embaucamiento ${ }^{23}$.

21 Jacobs, J. B./ Blitsa, D., «Paedophiles, employment discrimination, and European integration", en New York University Public Law and Legal Theory Working Papers, 2011, $\mathrm{n}^{\circ}$. 309, pp. 341-344, formulan interesantes interrogantes desde la perspectiva de la aplicabilidad de esta norma.

22 Salat Paisal, M., «Las consecuencias sancionadoras aplicables a los delincuentes sexuales tras las últimas reformas legislativas», cit., pp. 292-293, encuentra una explicación a los desajustes en el hecho de que el derecho del empresario se introdujo durante la tramitación de la norma por vía de enmiendas.

${ }^{23}$ El 14 de diciembre de 2017 el Parlamento Europeo aprobó una Resolución sobre la aplicación de la Directiva 2011/93/UE. Puede consultarse en el Anuario de Justicia Juvenil, 2017, $\mathrm{n}^{\circ}$. XVII. 
Estas dos últimas normas supranacionales específicamente centradas en luchar contra el abuso y la explotación sexual de los menores han influido marcadamente en la vigente regulación de los delitos sexuales con víctimas menores y también en las consecuencias jurídicas de estos delitos. No obstante, la revisión de estas últimas en distintos momentos desde la aprobación del CP de 1995 ha estado de manera muy importante condicionada por otros factores entre los que se encontraría la acentuación de la política punitivista dirigida a la inocuización de determinados delincuentes.

A resultas de todo ello se observa, y así lo iremos detallando en mayor o menor profundidad, que para hacer frente a los delitos sexuales con víctimas menores cometidos por personas físicas responsables penalmente se ha optado por el aumento de la duración de las penas de prisión, el endurecimiento del régimen de vida en prisión, el recurso a una medida penal postpenitenciaria (medida de seguridad de libertad vigilada), la ampliación de las penas cumulativas (así, las penas de alejamiento) junto con la introducción de penas aparentemente más novedosas (la pena de privación de la patria potestad y la pena de inhabilitación especial para cualquier profesión u oficio, sea o no retribuido, que conlleve contacto regular y directo con menores de edad), las inscripciones del ADN de los condenados en bases de datos, el establecimiento de una prohibición "administrativa" de acceso y ejercicio a las profesiones, oficios y actividades que impliquen contacto habitual con menores y la creación de un registro propio para delincuentes sexuales. A la luz de tal cúmulo de mecanismos casi sorprende que en un contexto de gran preocupación por la seguridad de la infancia y adolescencia en el ciberespacio no se haya introducido ya en el sistema una respuesta penal que restringiese o afectase a las formas de uso de las $\mathrm{TIC}^{24}$. El tiempo dirá si, como ha sucedido en el pasado en relación con alguna otra privación de derechos, no terminarán los juzgados aplicándola al amparo de la controvertida pena de inhabilitación especial para el ejercicio de cualquier otro derecho o como ya se ha hecho a través de otra vía ${ }^{25}$.

${ }^{24}$ Magro Servet, «La prohibición del uso de las redes sociales como pena en los delitos cometidos por internet», en $R J L, 2019, \mathrm{n}^{\circ} .9449$, pp.1-8, apunta diferentes vías para acordar en el presente este tipo de restricción, que, a nuestro juicio, podrían ser discutibles por distintos motivos.

La propuesta $\mathrm{n}^{\circ} .118$ del Informe de la Subcomisión creada en el seno de la Comisión de Igualdad para un pacto de estado en materia de violencia de género (núm. expte 154/2), aprobado por el Congreso de los Diputados en 2016, consistía en el establecimiento como medida cautelar y como pena privativa de derechos de la prohibición de comunicarse a través de las redes sociales en los delitos cometidos a través de las nuevas tecnologías.

25 Así el Juzgado de lo Penal $n^{\circ} 9$ de Barcelona en su sentencia $n^{\circ}$ 243/2019, de 29 de mayo, condenó a un "youtuber", en base a los artículos 48.1 y 57 del CP, a la prohibición de acudir a la red social de youtube por cinco años, al considerar que ese era el lugar del delito, lo que comportaba el cierre por este tiempo de su canal y la prohibición de crear otros durante este tiempo. 


\section{La intensificación del uso de la pena de prisión y el endurecimiento de su cumplimiento}

La expansión y la intensificación del uso de la pena de prisión en aras de la protección de los menores frente a determinados comportamientos de naturaleza sexual han sido una constante desde la aprobación del CP de 1995. Así a medida que se otorgaba relevancia penal a un mayor número de conductas humanas relacionadas con la sexualidad de los menores, castigadas además con pena de prisión, la duración de la pena de prisión ya existente se incrementaba; desapareciendo incluso en algún caso la pena típica alternativa a la misma.

En la actualidad todos los delitos sexuales contra menores tienen asociada una pena de prisión, que normalmente es además la única pena típica; contemplándose una pena de multa como alternativa a la misma sólo en el delito de abuso sexual del artículo 181.1 y del abuso sexual por prevalimiento del artículo 181.3 - de los que pueden ser víctimas los menores que ya han cumplido los 16 años y no sólo los adultos- ${ }^{26}$, en el delito de acceso a menores de 16 años con fines sexuales a través de las TIC del artículo 183 ter 1, en el delito de acoso sexual salvo en las modalidades del artículo 184.2 y 3 y en los delitos de exhibicionismo y provocación sexual (arts. 185 y 186). Asimismo es frecuente el recurso a la pena de prisión grave, esto es, aquella de duración superior a cinco años, la cual se contempla como pena típica en todos los abusos y agresiones sexuales cualificados que en su modalidad básica tienen asociada únicamente la pena típica de prisión y en las modalidades básicas de los abusos y agresiones sexuales a menores de dieciséis años del artículo 183. La reacción fuertemente punitivista frente a la delincuencia sexual condujo incluso a que en la gran reforma del CP por LO 1/2015 la comisión de un delito contra la libertad sexual al que subsigue el asesinato de la víctima determine que al autor de este asesinato se le castigue imperativamente con la denominada legislativamente pena de prisión permanente revisable (art. 140.1.2 $2^{\mathrm{a}}$.

La ley penal también ha endurecido el régimen de cumplimiento de la pena de prisión interfiriendo en el sistema penitenciario de individualización científica orientado hacia la resocialización de los penados mediante el establecimiento vía artículo 36.2 del CP del denominado periodo de seguridad, esto es, el tiempo necesario de cumplimiento de

\footnotetext{
26 Obsérvese, no obstante, que con la reforma del CP por LO 1/2015 algunos abusos sexuales de prevalimiento que tienen como víctima al menor de edad al que la ley reconoce capacidad para expresar un consentimiento sexual jurídicamente válido son subsumible en el artículo 182 en lugar de en el artículo 181. Inexplicablemente este cambio normativo ha comportado que en comparación con la regulación anterior la modalidad básica del tipo penal del artículo 182 se castigue de forma más grave, pero no así sus modalidades cualificadas, que reciben menor pena que las del tipo penal del artículo 181.4 y 5 .
} 
la pena de prisión antes de que el penado pueda ser clasificado en tercer grado y, consiguientemente, pueda cumplir la pena en régimen abierto. La aplicación del período de seguridad, prevista hasta el presente para todo condenado a una pena de prisión superior a cinco años ${ }^{27}$, se perfiló con carácter imperativo en el momento de su introducción en el CP (LO 7/2003), si bien se admitió la posibilidad de reconducir el cumplimiento de la pena al régimen general (es decir, el dispuesto en la LO 1/1979, General Penitenciaria - LOGP_-), si así lo acordaba razonadamente "el juez de vigilancia, previo pronóstico individualizado y favorable de reinserción social y valorando, en su caso, las circunstancias personales del reo y la evolución del tratamiento reeducador", "oídos el Ministerio Fiscal, Instituciones Penitenciarias y las demás partes”, y siempre que no se tratase de los delitos de terrorismo de la sección segunda del capítulo V del título XXII del Libro II del CP o cometidos en el seno de organizaciones criminales. Las críticas que suscitó esta regulación legal, especialmente por lo que significaba para el mandato de reeducación y reinserción social y para el principio de igualdad, condujeron a su modificación en la reforma del CP por LO 5/2010. Fue en esta reforma en la que, al tiempo que se flexibilizaba la aplicación del período de seguridad, se profundizó en su insoslayable imposición a determinados delincuentes ${ }^{28}$, entre los que se encuentran a partir de entonces los condenados por determinados delitos sexuales, concretamente los condenados por los delitos del artículo 183, esto es, abusos y agresiones sexuales a menores de 16 años tras la reforma de ese artículo por LO 1/2015, y por los delitos relativos a la prostitución, explotación sexual y corrupción de menores cuando la víctima sea menor de 13 años ${ }^{29}$. De forma que en la actualidad podemos hablar de un período de seguridad facultativo cuya aplicación decide el órgano sentenciador siempre que la pena de prisión impuesta sea superior a cinco años, susceptible de ser revocado a la luz de un pronóstico favorable de reinserción social. Una hipótesis que sería muy factible de darse a tenor de la duración de la pena de prisión legal abstracta asociada a una parte importante de los delitos sexuales en perjuicio de menores, pero que seguramente no lo sea tanto por el juego de las circunstancias modificadoras de la responsabilidad penal y la moderación punitiva de los jueces ${ }^{30}$. Y también de un período de seguridad impera-

27 Repárese en que, tras una controversia inicial, se considera que esa es la duración de la pena de prisión individual impuesta y no de la suma de las impuestas en caso de haber sido éstas varias.

28 Condenados por delitos referentes a organizaciones y grupos terroristas y delitos de terrorismo (cap. V, tít. XXII, L. II, CP) y por delitos cometidos en el seno de una organización o grupo criminal.

29 Obsérvese que el legislador no armonizó esta disposición con su decisión de elevar la edad de consentimiento sexual a los dieciséis años en la reforma de 2010.

30 En el estudio de Tamarit, J. M./ Guardiola, M. J./ Hernández-Hidalgo, P./ PadróSolanet, A., "La victimización sexual de menores de edad: un estudio de sentencias», en $R E I C, 2014, \mathrm{n}^{\circ} .12$, p. 26, cuyos resultados, no obstante, como bien advierten sus autores, no pueden ser generalizados, se señala que la mediana de penas impuestas es de menos 
tivo e irrevocable para el condenado a una pena de prisión superior a cinco años por los mencionados delitos sexuales, que no es necesario que expresamente se establezca en el fallo condenatorio dado que se trata de una regla de cumplimiento de la pena impuesta por ley.

Otra muestra más del importante papel que el legislador atribuye a la pena de prisión en este ámbito delictivo se manifiesta en la regulación de la suspensión condicional de la ejecución del resto de la pena. La LO $1 / 2015$, además de un cambio en la naturaleza jurídica de la libertad condicional, ahora consecuencia de la suspensión condicional de la ejecución del resto de la pena, diseñó un régimen de suspensión particular más favorable para los condenados primarios a pena de prisión no superior a tres años del que han quedado excluidos los condenados por delitos contra la libertad e indemnidad sexual (art. 90.3) ${ }^{31}$.

Por otra parte, y sin perjuicio de lo que se apuntará más adelante, hay que tener presente que toda pena de prisión lleva además consigo alguna o algunas penas accesorias de conformidad con los artículos 54-56 del $\mathrm{CP}^{32}$.

\section{Las penas privativas de derechos conectados con la función protectora de los menores}

\section{Observaciones previas}

La minoría de edad de una persona explica la necesidad de que ésta tenga que estar integrada en una institución protectora de Derecho de

de tres años de prisión, cuando casi la mitad de los delitos objeto de condena (agresiones sexuales, abusos sexuales y abusos sexuales a menores de trece años) podían haber sido castigado con penas de prisión de hasta ocho, doce o quince.

El estudio analiza un total de 366 sentencias dictadas en primera instancia por las Audiencias Provinciales de Andalucía, Cataluña, Galicia y Madrid, ascendiendo el número de víctimas a 420 .

31 Del mismo modo quedan también excluidos los condenados por delitos de terrorismo o cometidos en el seno de organizaciones criminales (art. 90.8).

Obsérvese también que la comisión de un delito contra la libertad e indemnidad sexual castigado con pena máxima de prisión de más de cinco años permite la expulsión del territorio de los ciudadanos de la UE residentes de larga duración — diez años- si se aprecia un riesgo grave de que el penado pueda cometer delitos de la misma naturaleza (art. 89.4).

32 Son penas accesorias la inhabilitación absoluta, la suspensión de empleo o cargo público, la inhabilitación especial para el derecho de sufragio pasivo, la inhabilitación especial para empleo o cargo público, profesión, oficio, industria, comercio, ejercicio de la patria potestad, tutela, curatela, guarda o acogimiento o cualquier otro derecho y la privación de la patria potestad. Bajo la rúbrica legal "De las penas accesorias" se regulan también las que podrían denominarse penas accesorias atípicas o sui generis que no están vinculadas a las penas principales sino a determinados delitos (art. 57). 
familia cuya función principal sería precisamente la de dispensarle la protección y el cuidado que su bienestar exige, garantizando su correcto desarrollo físico, mental, espiritual, moral, psicológico y social así como salvaguardando el pleno y efectivo disfrute de sus derechos.

La institución de referencia por excelencia a tal fin, dada la vinculación natural existente entre los progenitores y sus hijos, es la patria potestad, a la que están sometidos los hijos menores no emancipados - y aquellos hijos mayores de edad a quienes por su incapacidad se prorroga la patria potestad (art. $171 \mathrm{CC}$ )—. Esta institución se concibe modernamente como una función de responsabilidad parental comprensiva de una serie de deberes y facultades como son el "velar por ellos, tenerlos en su compañía, alimentarlos, educarlos y procurarles una formación integral" y el "representarlos y administrar sus bienes", que se han de ejercer siempre en interés de los hijos, de acuerdo con su personalidad, y con respeto a sus derechos, su integridad física y mental (art. 154 CC). Disposición ésta a través de la que se da concreción al mandato constitucional que establece el deber de los padres de "prestar asistencia de todo orden a los hijos habidos dentro o fuera del matrimonio durante la minoría de edad..." (art. $39.3 \mathrm{CE}$ ). El interés superior del menor, que, como bien es sabido, constituye uno de los ejes sobre los que gravita el $\mathrm{CDN}$ y la legislación de protección de los menores, requiere asimismo de la previsión de otras instituciones tuitivas del menor que de forma más o menos intensa coadyuven o reemplacen, en atención a las concretas circunstancias, a la patria potestad como son en nuestro derecho la tutela, la curatela, la guarda o el acogimiento y las instituciones análogas de Derecho foral. Instituciones que, en consideración a su finalidad, exigen que la persona nombrada para ejercer ese cargo o responsabilidad reúna las condiciones que le hagan idónea para desempeñarlo y determinan, al igual que sucede con la patria potestad, la atribución a aquella de una serie de derechos-deberes.

El incumplimiento de los deberes-derechos de los titulares de todas estas instituciones exige obviamente de una respuesta por parte del Derecho que, en función de las circunstancias concurrentes y el interés superior del menor, puede ser diversa. Si focalizamos nuestra atención en el marco de la comisión de un delito sexual por parte de la persona que ostenta estos cargos en perjuicio del menor protegido es evidente que nos encontraríamos ante un incumplimiento grave de los deberes de protección del menor ante la puesta en peligro o lesión que la conducta causa al menor en su proceso de formación en la esfera sexual o, en su caso, en su libertad sexual; un incumplimiento revelador asimismo de la falta de capacidad de aquel para seguir cumpliendo con esta función. Pero además tal conducta podría ser sintomática de su inidoneidad para desempeñar tales funciones en relación con cualquier otro menor. Así las cosas las medidas previstas en el CC para prevenir el incorrecto ejercicio de las funciones de protección del menor con el objetivo exclusivo de proteger al menor (tal es el caso de la adopción de algunas de las medidas del artí- 
culo 158, la privación total o parcial de la patria potestad —art. 170—33, la remoción de la tutela y de la curatela —arts. 247 y 291-, el establecimiento de causas de inhabilitación para ser tutor - arts. 243 y 244-, curador — art. 291-, acogedor — art. 172 ter 1 -), resultarían plenamente aplicables ante esos hechos. Algunas de ellas, por vía de la cláusula abierta del artículo 158 del CC ("en general, las demás disposiciones que considere oportunas, a fin de apartar al menor de un peligro o de evitarle perjuicios en su entorno familiar o frente a terceras personas"), serían susceptibles de aplicarse también en el propio proceso penal, de oficio o a instancia del propio hijo, de cualquier pariente o del Ministerio Fiscal. No obstante lo dicho, durante un tiempo se trataba ésta de una cuestión controvertida en la práctica pues el debate jurídico, originado antes de la reforma de ese artículo 158 del CC por la LO 1/1996, de 15 de enero, de protección jurídica del menor ${ }^{34}$, se había situado específicamente sobre la interpretación del artículo 170 del CC que sencillamente afirma que "el padre o la madre podrán ser privados total o parcialmente de su potestad por sentencia fundada en el incumplimiento de los deberes inherentes a la misma o dictada en causa criminal o matrimonial", habiéndose interpretado éste en la sentencia del Tribunal Supremo, Sala Segunda, $\mathrm{n}^{\circ}$. 780/2000, de 11 septiembre, en el sentido de que “... no establece una dualidad de cauces procesales alternativos para la común aplicación —en el proceso civil o en el proceso penal- de la privación de patria potestad por incumplimiento de sus deberes inherentes; sino que para privar de la patria potestad la alternatividad se establece precisamente entre de una parte una Sentencia fundada en el incumplimiento de los deberes inherentes a ella, y de otra parte una Sentencia dictada en causa criminal, es decir, que o bien se priva de la patria potestad por Sentencia fundada en

33 Se contempla también en el CC la exclusión de la patria potestad para los condenados penalmente a causa del hecho que da lugar al nacimiento del menor (art. 111). A diferencia de la privación de la patria potestad del artículo 170, la exclusión, según nos explica Castillo Martínez, C. del C., La privación de la patria potestad. Criterios legales, doctrinales y judiciales, $2^{\mathrm{a}}$ ed. La Ley, Madrid, 201, pp. 124-129, tiene un efecto declarativo ante el supuesto descrito y presupone que el excluido nunca ha ostentado la titularidad sobre la misma. Se trata, por tanto, de una exclusión automática por imperativo legal, que además conlleva que el excluido no ostentará derechos por ministerio de la ley respecto del hijo o de sus descendientes o en sus herencias; conservando su naturaleza de sanción. Precisamente por ello no es de aplicación la recuperación de la patria potestad prevista en el artículo 170 párrafo $2^{\circ}$; si bien la restricción dejará de producir efecto por determinación del representante legal del hijo aprobada judicialmente o por voluntad del propio hijo una vez alcanzada la plena capacidad (art. $111 \mathrm{CC}$ ).

La exclusión de la patria potestad también se produce cuando la filiación ha sido judicialmente determinada contra su oposición.

${ }_{34}$ Recuérdese que la posibilidad de articular estas medidas en un proceso penal se produce a partir de la reforma del artículo 158 del CC por la LO 1/1996, de 15 de enero, de protección jurídica del menor, de modificación parcial del CC y de la Lec., entre cuyos objetivos se encontraba la clarificación de los trámites de los procedimientos administrativos y judiciales que afectaban a los menores para evitar su indefensión o desprotección imprimiendo a los mismos agilidad e inmediatez (Exposición de motivos II). 
tal incumplimiento o bien se priva de ella en una causa criminal; lo que necesariamente supone que no cabe en (el) proceso penal privar de la patria potestad por razón del cumplimiento obligacional que es lo propio de la otra alternativa prevista, sino por las causas y en los casos establecidos en las normas penales, es decir en el CP, que ..., no permite la imposición de tal pena en el presente caso", (FJ. $\left.4^{\circ}\right)^{35}$. A la luz de lo dicho, concluiría este tribunal que la jurisdicción penal, por falta de previsión legal $^{36}$, carecería de competencia para aplicar esas medidas civiles ${ }^{37}$.

También cuestionada fue en su día la posibilidad de aplicar una pena privativa del ejercicio de los derechos conectados con la función protectora de los menores al amparo de la pena de inhabilitación especial para el ejercicio de cualquier derecho por mor del principio de legalidad de

35 Una lectura de la norma opuesta a ésta la encontramos en la sentencia del Tribunal Supremo, Sala de lo Penal, $n^{\circ} .2615 / 1993$ de 20 diciembre, (FJ. $2^{\circ}$ ): "Aunque es evidente que, en principio, las decisiones sobre la patria potestad son materia reservada a la jurisdicción civil, tal reserva se produce salvo una remisión expresa de la ley a otro orden jurisdiccional. Remisión que existe a la jurisdicción penal en el art. 170 CP y que no puede interpretarse en el sentido restringido de que la sentencia dictada en causa criminal lo sea expresamente por delito que lleve aparejada como sanción la privación de tal potestad paterna. Y ello por dos órdenes de razones: El primero, por cuanto la unidad jurisdiccional (art. 3.1 LOPJ), tiene carácter expansivo exigiendo sólo para que un concreto órgano pueda juzgar una cuestión que exista atribución expresa de la LOPJ u otra Ley (art. 9..$^{\circ}$ LOPJ); por lo que si existe atribución legal se produce una extensión de la jurisdicción a cuestiones que, en principio, puedan ser competencia de otros órdenes jurisdiccionales. Y la atribución legal expresa a la jurisdicción penal en este caso se encuentra en la fórmula alternativa del citado art. 170, precepto que debe ser interpretado en sentido extensivo y teológico, en favor del mejor cumplimiento del fin de la norma que no es otra que la más eficaz y pronta tutela del interés del menor. El segundo, porque la propia economía procesal y el citado interés del menor - que, conviene no olvidarlo, es lo prevalente en estos casos-, exige que, constatado por un Tribunal al ejercer su jurisdicción enjuiciando un hecho concreto que le viene competencialmente atribuido, que tal hecho revela un grave incumplimiento de los deberes de la patria potestad y un daño para el hijo, no se dilate más la privación de aquella potestad que se está ejerciendo con daño grave al menor, más aún cuando ese daño, de permanecer en el tiempo, puede ser irreversible".

36 Un ejemplo de previsión legal lo encontramos en el artículo 193 del CP, que señala que "en las sentencias condenatorias por delitos contra la libertad sexual, además del pronunciamiento correspondiente a la responsabilidad civil, se hará, en su caso, lo que procedan en orden a la filiación y fijación de alimentos".

37 FJ. 4: "Tampoco cabe en este caso acordar la privación de la patria potestad mediante la directa aplicación por el Tribunal penal de las normas de Derecho de familia, que dentro del ámbito del Derecho Privado, disciplinan aquella institución, y cuya aplicación compete a la jurisdicción civil, por los órganos integrados en ella a través de los procedimientos civiles correspondientes. Los Juzgados y Tribunales ejercen su jurisdicción exclusivamente en aquellos casos en que les venga atribuida por la Ley tal como dispone el artículo $9.1^{\circ}$ de la LOPJ. Corresponde al orden jurisdiccional penal el conocimiento de las causas y juicios criminales (art. 9.3 LOPJ), ámbito jurisdiccional al que pertenecen las normas del CP sobre privación de la patria potestad como pena principal o accesoria, no las sanciones civiles que en la esfera del Derecho Privado y con relación a patria potestad corresponden según el CC en caso de incumplimiento de los deberes familiares". 
las sanciones penales ${ }^{38}$; conflicto extrapolable al marco de las medidas de seguridad dada la previsión de una medida de seguridad de inhabilitación para el ejercicio de determinado derecho (art. 107), a la que se podría pretender anclar una medida de seguridad privativa del ejercicio de los derechos conectados con la función protectora de los menores ${ }^{39}$. Lo dicho no impidió que los tribunales aplicasen este tipo de pena, como pena accesoria, al amparo del artículo 56, llegando incluso, por razones de justicia material, a imponerla claramente en casos no previstos en la ley. Expansión punitiva esta última que finalmente rechazó el Pleno de Sala de lo Penal del Tribunal Supremo en su acuerdo no jurisdiccional de 26 de mayo de 2000 , donde se afirma la imposibilidad de imponer esta pena como pena accesoria de la pena de prisión superior o igual a diez años por no estar prevista en la Ley ${ }^{40}$.

En un escenario jurídico tan confuso como el que acabamos de describir y en un clima de reforzamiento del interés por la protección de los menores la apelación clara al establecimiento de mecanismos penales privativos o restrictivos del ejercicio de esas funciones, que ejerzan un control del riesgo de la peligrosidad futura del sujeto en relación con terceros menores y que además, a diferencia de las citadas medidas civiles carentes de una finalidad retributiva ${ }^{41}$, se presenten ante los ojos de la

${ }^{38}$ El hecho de que el legislador prevea la pena de inhabilitación especial para cualquier otro derecho originó, como señala Boldova Pasamar, M. A., «Penas privativas de derechos», en Gracia Martín, L., (coord.), Lecciones de consecuencias jurídicas del delito, $4^{\mathrm{a}}$ ed. Tirant lo Blanch, Valencia, 2012, p. 66, un sistema abierto de inhabilitaciones especiales cuestionable desde el principio de legalidad de las penas y su mandato de certeza, si bien, según señala Quintero Olivares, G., «Las penas en el siglo XXI, reflexiones obligatorias», en Roca Agapito, L., (dir.), Un sistema de sanciones penales para el siglo XXI, Ed. Tirant lo Blanch, Valencia, 2019, en prensa, había nacido con la loable finalidad de evitar que estas penas supusieran demasiadas privaciones innecesarias de forma que en virtud de esta referencia genérica se pudiera modular el contenido de la pena.

Ese sistema permitió que, antes de la reforma de 2010, se aplicase como pena accesoria de la pena de prisión inferior a diez años la pena de inhabilitación especial para el ejercicio de la patria potestad y demás cargos cuando el ejercicio de estos derechos hubieran tenido relación directa con el delito, tal y como se refleja en la jurisprudencia. Su falta de previsión en algunos delitos muy graves, como el homicidio, de los que podría haber sido incluso víctima el propio menor, había sido observada por algunos autores, así Rey Huidobro, L. F., «La pena de inhabilitación especial para el ejercicio de la patria potestad, tutela, curatela, guarda o acogimiento», en $R J L, 2004, \mathrm{n}^{\circ} .6007, \mathrm{p} .3$.

${ }_{39}$ Aunque considera técnicamente defectuosa la redacción Guinarte Cabada, G., «La pena de inhabilitación especial de los derechos de patria potestad, tutela, guarda o curatela», en Faraldo Cabalda, P./ Puente Aba, L. M., (dirs.), Las penas privativas de derechos y otras alternativas a la privación de libertad, Ed. Tirant lo Blanch, Valencia, 2013, pp. 133134, defiende su inclusión en el artículo 107.

${ }^{40} \mathrm{La}$ primera sentencia en la que aplica ese acuerdo fue la sentencia del Tribunal Supremo, Sala de lo Penal, $\mathrm{n}^{\circ} .780 / 2000$, de 11 de septiembre (FJ. $4^{\circ}$ ). Ampliamente sobre la cuestión Ruisánchez Capelástegui, C., «Privación de la patria potestad y proceso penal. Comentario a la STS, $2^{\mathrm{a}}, 28.4 .2006 »$, en Indret, 2007, $\mathrm{n}^{\circ} .4$.

${ }^{41}$ En esta línea también Castillo Martínez, C. del C., La privación de la patria potestad. Criterios legales, doctrinales y judiciales, cit., p. 168, quien recoge diversas resoluciones 
sociedad con la carga emotiva de una sanción penal justa por el comportamiento realizado parecía justificarse desde consideraciones de política criminal $^{42}$. Y así lo ha entendido también nuestro legislador, si bien en el caso concreto de la victimización sexual de los menores el ropaje con el que ha revestido formalmente a la privación de derechos conectados con la función protectora de los menores prevista en el CP, el de penas, una vez que han devenido inadmisibles las penas infamantes (art. $15 \mathrm{CE}$ ), no necesariamente resulta incontrovertido dado que frente a la idea de justicia retributiva y la finalidad preventiva general, tan características de las penas, prevalece claramente en esta sanción penal la finalidad de controlar la peligrosidad criminal del sujeto para impedir que la ostentación de las funciones protectoras de un menor le coloque en la posición de poder reincidir en esos delitos ${ }^{43}$.

Las penas a las que nos referiremos seguidamente, la pena de privación de la patria potestad y la pena de inhabilitación especial para el ejercicio de los derechos de la patria potestad, tutela, curatela, guarda o acogimiento, englobadas legislativamente dentro del heterogéneo grupo de las penas privativas de derechos - Libro I, título III, cap. 1, secc. $3^{\text {a }}$ (arts. 39-49) y secc. $5^{\text {a }}$ (arts. 55-57) del CP-, entroncan con la histórica pena —en algún momento también medida de seguridad (CP de 1928)— de interdicción civil ${ }^{44}$, cuya supresión de la escala general de penas del CP anterior ${ }^{45}$, en la reforma operada por LO 8/1983, de 25 de junio, de reforma urgente y parcial del CP (art. 27), se vio acompañada del vaciado de contenido del artículo $43^{46}$, perviviendo, sin embargo, la facultad

judiciales donde prevalece la naturaleza protectora de la medida.

${ }^{42}$ Los distintos presupuestos fácticos y normativos de este tipo de privaciones de derechos previstas en las disposiciones civiles y en las penales hacen que la privación acordada en la vía civil o administrativa no se pueda abonar si posteriormente se dicta una condena penal con un contenido igual. Así Auto de la Audiencia Provincial de Tarragona (Sección 4a), nº. 407/2012, de 30 julio (FJ. Único).

43 A favor de su configuración como medida de seguridad se ha manifestado Tamarit Sumalla, J. M., «Sección $3^{\mathrm{a}}$. De las penas privativas de derechos», en Quintero Olivares, G., (dir.), Comentarios al Código penal español. Tomo I (Artículos 1 a 233), Ed. Aranzadi, Navarra, 2016, p. 466, quien además apunta que ello evitaría tener que iniciar un procedimiento civil para alcanzar el mismo objetivo en los casos de los sujetos inimputables. La discusión sobre la naturaleza jurídica de este tipo de privaciones de derechos civiles no es nueva, vid. Manzanares Samaniego, J. L., «La pena de interdicción civil», en ADPCP, 1979, Tomo 32, Fasc/Mes 2, pp. 353-363.

44 Vid. Manzanares Samaniego, J. L., «La pena de interdicción civil», cit., pp. 346-349.

45 Señala Tamarit Sumalla, J. M., «Sección $3^{\text {a }}$. De las penas privativas de derechos», cit., p. 465, que el motivo de su supresión fue su incompatibilidad con el mandato resocializador.

46 El Decreto 3096/1973, de 14 de septiembre, por el que se publica el CP, texto refundido conforme a la Ley 44/1971, de 15 de noviembre, consideraba a la pena de interdicción civil una pena accesoria consistente en la privación al penado de los derechos de patria potestad, tutela, participación en el consejo de familia, de la autoridad marital, de la administración de bienes y del derecho de disponer de los propios por actos entre vivos (arts. 27 y 43). 
del juez de acordar la privación de la patria potestad y de la tutela a los culpables de, entre otros, los delitos sexuales (art. 452 bis g) ${ }^{47}$, y la imposición de la interdicción civil a determinados cómplices de los delitos sexuales y a los condenados por delitos de corrupción de menores en interés de terceros (art. 446).

Ambas penas, aunque cumplen la doble función de pena principal y pena accesoria, están previstas en los delitos sexuales como penas principales facultativas, alternativas además entre sí. Consiguientemente su aplicación judicial está condicionada por la existencia de la correspondiente petición por una parte acusadora, en la medida en que de conformidad con el artículo 789.3 de la LECr. "la sentencia no podrá imponer pena más grave de la solicitada por las acusaciones". Esto no sucedería si actuasen como penas accesorias por ser éstas imperativas por ley (art. 79).

\section{La pena de privación de la patria potestad}

El origen de la vigente pena de privación de la patria potestad se encuentra en la LO 5/2010, de 22 de junio, por la que se modifica la LO 10/1995, en cuyo Preámbulo se explica que su establecimiento como pena responde al hecho de "completar el elenco de normas destinadas a otorgar mayor protección a los menores" (XIII último párrafo) ${ }^{48}$. Aquí también anticipa el legislador su doble función de pena accesoria, de

47 Así los delitos de abandono de familia del artículo 487, los relativos a la utilización de menores en la mendicidad del artículo 489 bis (aquí también se mencionaba la guarda) o las faltas consistentes en dejar de cumplir los deberes de la patria potestad, tutela o guarda (art. $5841^{\mathrm{o}}$ y $2^{\mathrm{a}}$ ). En relación con estas últimas se mencionaba la suspensión del ejercicio de los derechos inherentes a la patria potestad o a la tutela sobre el menor.

${ }^{48}$ Los textos prelegislativos mediante los que se encauzó esta reforma del CP, desde el Anteproyecto de LO de modificación de la LO 10/1995, de 23 de noviembre, del CP, aprobado por el Consejo de Ministros el noviembre de 2008, hasta el Proyecto de LO, publicado en el BOCG el 27 de noviembre de 2009, incidieron en mayor medida en el motivo de la incorporación de esta previsión legal; haciéndose eco así, aunque sin exponerlo claramente, de la problemática existente sobre si un juez de lo penal podía acordar la medida civil de privación de la patria potestad. A tenor de la justificación de la introducción de esta pena, Ruisánchez Capelástegui, C., «Nota sobre la privación de la patria potestad en el anteproyecto de modificación del Código Penal», cit., p. 8, parece considerar que en realidad se trata de una institución civil. 
toda pena de prisión ${ }^{49}$, y pena principal ${ }^{50}$; desarrollándose esta última sólo en el ámbito de los delitos sexuales (art. 192.2), lo que es sintomático de esa intensificación de la respuesta penal frente al delincuente sexual $^{51}$.

Su previsión como pena principal en esos delitos, aunque expresamente no lo indique así el CP, a diferencia de lo que ocurre con las penas de inhabilitación (art. 54), posiblemente ante el descuido y la inercia de las reformas penales, ha de llevarnos a la conclusión de que en los delitos sexuales esta pena sólo actúa en realidad como pena principal. Así lo avalaría una interpretación sistemática de las normas y la propia razón de ser de las penas accesorias, las cuáles de acuerdo con su propia naturaleza están pensadas para acompañar a la pena de prisión sólo en aquellos casos en los que no se ha previsto su imposición de forma especial. No obstante, esta precisión no tendrá mayor trascendencia en este caso si tenemos presente que el efecto de esta pena es perpetuo.

A tenor del artículo 46 esta pena, siempre grave en atención a la entidad e intensidad de los derechos afectados por la misma (art. 33.2.K), implica la pérdida de la titularidad de la patria potestad —incluida la prorrogada, como la de las instituciones análogas previstas en la legislación civil de las Comunidades Autónomas-, subsistiendo los derechos de los que sea titular el hijo respecto del penado ${ }^{52}$. Consiguientemente el penado al carecer a partir de ese momento de la patria potestad sobre el hijo experimentará una desconexión de su responsabilidad parental que no será, sin embargo, absoluta en la medida en que el artículo 46, como acabamos de apuntar, afirma la subsistencia de los derechos de los que sea titular el hijo respecto del penado. Desde el momento en que la patria potestad abarca correlativos deberes-derechos entre los padres y sus hijos relacionados específicamente con la protección de los intereses personales y económicos de los últimos es necesario delimitar exactamente

49 La reforma del CP por la LO 5/2010 reformó los artículos 55 y 56, dando así respuesta a los problemas de legalidad penal anteriormente apuntados. Se introducen en concreto como penas accesorias la pena de privación de la patria potestad y la inhabilitación especial para el ejercicio de la patria potestad, tutela, curatela, guarda o acogimiento; que pueden vincularse a cualquier pena de prisión siempre que esos derechos hubieran tenido relación directa con el delito cometido.

50 Apuntaba la necesidad de que se configurase también como medida de seguridad Ruisánchez Capelástegui, C., «Nota sobre la privación de la patria potestad en el anteproyecto de modificación del Código Penal», en Indret, 2009, nº. 2, p. 7.

51 Souto García, E. M., «La pena de privación de la patria potestad», en Faraldo Cabalda, P./ Puente Aba, L. M., (dirs.), Las penas privativas de derechos y otras alternativas a la privación de libertad, Ed. Tirant lo Blanch, Valencia, 2013, pp. 171-172, indica una segunda razón: el hecho de que el ámbito doméstico sea uno de los espacios de elevado riesgo de ser agredido.

52 Genéricamente habla de derechos de naturaleza asistencial Messía de la Cerda Ballesteros, J. A., «La privación de la patria potestad por sentencia penal», en La Ley Derecho de Familia: Revista Jurídica sobre Familia y Menores, 2016, nº. 12, p. 6. 
cuáles son los derechos subsistentes del hijo. A tal fin, considerando que toda pena, por su naturaleza, ha de comportar una carga para el penado y que esta pena en concreto tiene un marcado enfoque preventivo especial que requiere de la separación del padre del hijo, cabría entender que únicamente pervive el derecho de los hijos a que se abonen los gastos de sus alimentos; entendidos éstos civilmente como los gastos de sustento, habitación, vestido, asistencia médica, educación e instrucción (arts. 142 y 143.2 CC). El sentido penal de esta privación de la patria potestad comportaría entonces por su contenido una mayor gravosidad que la medida civil homónima dado que con arreglo al artículo 110 del CC aunque el padre y la madre no ostenten la patria potestad, lo que acontece cuando son privados de su titularidad, están obligados no sólo a prestarles alimentos sino también a velar por ellos lo que implica que mantendrían el derecho a solicitar información sobre las circunstancias en las que se encuentra el hijo.

La previsión en estos delitos como alternativa a la pena de privación de la patria potestad de la pena de inhabilitación especial para el ejercicio de la patria potestad refuerza esa conclusión que implica negar asimismo el derecho a la comunicación entre hijos y padres ${ }^{53}$; sin que tal conclusión signifique una oposición a lo dispuesto en el artículo 160.1 del CC ("los hijos menores tienen derecho a relacionarse con sus progenitores aunque éstos no ejerzan la patria potestad, salvo que se disponga otra cosa por resolución judicial o por la Entidad Pública en los casos establecidos en el artículo $161 \ldots{ }^{\prime 54}$ ), dado que de acuerdo con éste el derecho de comunicación subsiste aunque los padres no ejerzan la patria potestad, pero no aunque los padres hayan sido privados de la titularidad de la patria potestad, que son dos cosas bien distintas.

Ahora bien, la posibilidad de que existan interpretaciones opuestas sobre este particular hace recomendable que el legislador penal se manifieste expresamente sobre los derechos subsistentes del hijo, cumpliendo así mejor con el mandato de certeza. Hasta que esto suceda, la labor judicial en el momento de la individualización de la pena o, en su defecto, en el trámite de ejecución de la sentencia va a ser transcendental para evitar futuros conflictos derivados de un incorrecto entendimiento de los derechos que subsiste en relación con el hijo; incluida la presunta comisión de un delito de quebrantamiento de condena. Otra vía a través de la cual se pueden evitar ulteriores problemas es mediante la aplicación de la prohibición de comunicación, que responde a la misma finalidad, pero ésta tiene una duración temporal (arts. 48.2 y 57), lo que hace que

53 Sobre la privación de la patria potestad y este derecho vid. Castillo Martínez, C. del C., La privación de la patria potestad. Criterios legales, doctrinales y judiciales, cit., pp. 296-303.

54 El artículo 161 CC se refiere a los menores en situación de desamparo. 
la satisfacción de la finalidad pretendida dependa a la postre de la edad del hijo.

En atención a la finalidad preventiva especial de esta pena la privación de la patria potestad no necesariamente supone que la víctima del delito que motiva la condena penal tenga que ser el hijo respecto del que se pierde la titularidad de patria potestad. A esta conclusión no se opone el tenor del artículo 192.3, que se limita a decir que "el Juez o Tribunal podrá imponer razonadamente, además,... la privación de la patria potestad", perdiendo valor, tras la reforma del CP por LO 5/2010, por la que se introduce en el artículo 192.1 la medida de seguridad de libertad vigilada, cualquier intento de restringir su ámbito de aplicación a partir de una interpretación sistemática de esta disposición con la contenida en el artículo 192.2, referida exclusivamente a personas que ejercen funciones de protección de los menores ${ }^{55}$. Tampoco representa un obstáculo la precisión contenida en el artículo 46 párrafo $1^{\circ}$ inciso final, según la cual "el Juez o Tribunal podrá acordar estas penas respecto de todos o de alguno de los menores o personas con discapacidad necesitadas de especial protección que estén a cargo del penado, en atención a las circunstancias del caso". Ciertamente la redacción de esta disposición no es la más apropiada tras su extensión a la pena de privación de la patria potestad pero está claro que así ha sido por el uso del plural.

De esta disposición general se deriva asimismo que, en caso de que el juez determine la aplicación de esta pena, el penado perderá la titularidad de la patria potestad siempre respecto del hijo víctima del delito, debiéndose ponderar si procede respecto de los otros hijos que se encuentren bajo su patria potestad ${ }^{56}$. En relación con ninguna de las decisiones judiciales el legislador establece parámetro alguno en los que el juez pueda fundamentar su decisión, limitándose a apelar de forma genérica a las circunstancias del caso. Junto al criterio general de aplicación de la pena concerniente a los fines de ésta, que en este caso es marcadamente preventivo especial, cobra especial interés por mor del contenido de la pena el interés superior del menor. Un concepto jurídico indeterminado que llevará en definitiva al juez de lo penal a pronunciarse sobre si el condenado está o no en condiciones de cumplir correctamente con la función de la patria potestad.

55 De otra opinión Souto García, E. M., «La pena de privación de la patria potestad», cit., p. 171; aunque en página 181 refiriéndose a esta pena en general sí acepta que se pueda aplicar aunque la víctima del delito no sea hijo del penado.

56 Souto García, E. M., «La pena de privación de la patria potestad», cit., p. 181, se pregunta si sería posible que esta pena afectara a una futura patria potestad del condenado. A nuestro juicio, y sin adentrarnos en otro tipo de consideraciones, el propio tenor literal del artículo 46 responde negativamente a esta cuestión dado que presupone que los menores están a cargo del penado. Así las cosas, en caso de que una persona que hubiese sido condenada a esta pena tuviera posteriormente otros hijos la vía a la que habría que recurrir para prevenir el peligro que éste pudiera representar para éstos sería la vía civil. 
La previsión en el artículo 192.3 de esta pena como pena alternativa a la pena de inhabilitación especial para el ejercicio de la patria potestad, tutela, curatela, guarda y acogimiento genera en cierta medida una merma en la protección de los menores sujetos a estas otras instancias protectoras, en comparación con lo que sucede al amparo de la pena de inhabilitación especial alternativa, dado que si bien las normas civiles impiden que una persona privada de la patria potestad pueda ser elegida para esos cargos y obligan a que ésta sea removida de su cargo cuando incurre en esa causa de inhabilidad, en este último caso sería necesario abrir un nuevo procedimiento en la vía civil para evitar que el penado siguiese ostentando el cargo. En cambio cuando se impone la mencionada inhabilitación especial ese efecto se consigue inmediatamente.

A la luz de su contenido y de la falta de asignación a la misma de una duración temporal cabría sostener que estamos ante una pena de efecto instantáneo que perdura en el tiempo, impidiendo que en algún momento el penado pudiera recuperar tal derecho; una suerte de pena de duración indefinida o definitiva ${ }^{57}$. A resultas de lo dicho, no es admisible que se plantee, a diferencia de lo que sucede con la medida civil de privación de la patria potestad, donde el interés superior del menor es el fundamento para su aplicación y el posterior condicionante de su pervivencia, su recuperación al amparo del artículo 170 párrafo $2^{\circ}$ del $\mathrm{CC}^{58}$. Conclusión que también se puede extraer del tenor literal de ese artículo,

57 Así Boldova Pasamar, M. A., «Penas privativas de derechos», en Gracia Martín, L., (coord.), Lecciones de consecuencias jurídicas del delito, cit., p. 81; Gutiérrez Castañeda, A., «Penas privativas y restrictivas de derechos», en Roca Agapito, L. de, Las consecuencias jurídicas del delito, Ed. Tirant lo Blanch, Valencia, 2016. p. 57; Gil Gil, A./ Lacruz López, J. M./ Melendo Pardos, M./ Núñez Fernández, J., Consecuencias jurídicas del delito. Regulación y datos de la respuesta a la infracción penal en España, Ed. Dykinson, Madrid, 2018, p. 178.

${ }^{58}$ Igualmente el Informe del Consejo Fiscal sobre el anteproyecto de LO por la que se modifica la LO 10/1995, de 23 de noviembre, del CP, de 2008, p. 27; el Dictamen del Consejo de Estado al Anteproyecto de LO por la que se modifica la LO 10/1995, de 23 de noviembre, del CP, de 2009, (séptima), donde se plantea, por razones de unidad del ordenamiento jurídico, el establecimiento de una mecanismo que permita compatibilizar la privación de la patria potestad penal con su rehabilitación. De otra opinión el CGPJ, en su Informe al anteproyecto de LO por la que se modifica la LO 10/1995, de 23 de noviembre, del CP, de 2009, p. 105, quien observaba como efectivamente en los preceptos de la parte general relativos a esta pena no se precisaba su carácter definitivo pero sí en su uso en el artículo 192.2, recomendando que se eliminase de aquí su carácter definitivo.

Consideran aplicable el mecanismo de rehabilitación Ruisánchez Capelástegui, C., «Nota sobre la privación de la patria potestad en el anteproyecto de modificación del Código Penal», cit., p. 6, quien no obstante configurarse la privación de la patria potestad como pena entiende que no debe deslindarse de la figura civil; Messía de la Cerda Ballesteros, J. A., «La privación de la patria potestad por sentencia penal», cit., p. 5. También lo acepta Flores Rodríguez, J., «La privación de la patria potestad en los delitos sexuales contra menores», en $L P, 2012, \mathrm{n}^{\circ} .90$, p. 15, (consulta online). En contra Villacampa Estiarte, C., «Penas accesorias», en Álvarez García, F. J./ González Cussac, J. L., (dirs.), Comentarios a la reforma penal de 2010, Ed. Tirant lo Blanch, Valencia, 2010, p. 117; Souto García, E. M., «La pena de privación de la patria potestad», cit., pp. 176-178. 
que otorga a los tribunales la facultad de acordar la recuperación de la patria potestad en beneficio e interés del hijo, exigiendo además, de forma lógica, que haya cesado la causa que motivó la privación de la patria potestad. Y ello es así porque, como hemos visto, la pena de privación de la patria potestad no se fundamenta legislativamente en el interés superior del menor, si bien éste explica rotundamente su necesidad, sino en la culpabilidad del penado por el hecho realizado; dándose además la particularidad de que por ser la causa de la privación de la patria potestad la comisión de un delito no podemos afirmar que se haya producido entre el momento en que se impuso la pena y un momento posterior una cesación de la causa que la motivó. En este orden de cosas, podría ser adecuado, pensando en el interés superior del menor, reflexionar sobre la conveniencia de introducir un mecanismo penal rehabilitador de la titularidad de la patria potestad.

La pérdida de la patria potestad lleva aparejada otras consecuencias colaterales de naturaleza civil. Así el penado no tendrá derecho a que le sea notificada la resolución administrativa en virtud de la cual se constituye la guarda sobre su hijo (art. 172 ter 1) o se delegue en un tercero la guarda del hijo declarado en situación de desamparo con fines de adopción (art. 176 bis), ni tampoco a asentir la adopción por un tercero de su hijo (art. 177.2. $2^{\circ}$ ) o a ser oído al respecto (art. 177.3.1 ${ }^{\circ}$ ), devendrá inidóneo para adoptar (art. 176.3), para ser tutor o curador - en su caso dejará de serlo- (arts. 243.1, 247 y 291), estará incurso en causa legal de indignidad para suceder (art. $756.2^{\circ}$ ), así como en causa justa legal para que sus descendientes o su cónyuge le desherede (arts. 854 y 855, si bien la reconciliación entre ofensor y ofendido priva a éste del derecho a desheredar).

\section{La pena de inhabilitación especial para el ejercicio de los derechos de la patria potestad, tutela, curatela, guarda o acogimiento}

La LO 10/1995, del CP, dispuso una nueva modalidad de pena de inhabilitación especial que incidía en los derechos conectados con la función protectora de los menores, reintroduciendo así algunos efectos de la antigua pena de interdicción civil. En concreto esta inhabilitación especial afecta a los derechos de patria potestad, tutela, guarda, curatela y acogimiento, tal y como específica el artículo 46 del CP tras haberse omitido en el artículo 39 b la mención del acogimiento, no obstante las cuatro ocasiones en las que este artículo se ha reformado.

Originariamente la única función que se asignó con claridad a esta pena fue la de pena principal, pero desde la reforma del CP por LO 5/2010 desempeña también, sin discusión posible motivada por razones de legalidad penal, el papel de pena accesoria de toda pena de prisión. 
Bajo la primera de las facetas mencionadas, esta pena aparece vinculada a contadas infracciones, entre las que se encuentran los delitos sexuales del Título VIII. A la luz de la disposición de esta pena en los preceptos de la parte especial del CP habría que precisar además que si bien en el artículo 46 del CP esta inhabilitación se aborda como si de una única pena se tratase, lo cierto es que nuestro legislador modula sus efectos en cada delito concreto; pudiéndose apreciar como algún tipo penal señala únicamente la inhabilitación especial para el ejercicio de la patria potestad (así el art. 225 bis). Asimismo se observa que en alguna ocasión el legislador no menciona el elenco completo de instituciones protectoras distintas de la patria potestad, omitiendo la referencia a la privación de los derechos de curatela en el artículo 226 o al acogimiento en el artículo $221.1^{59}$. Posiblemente esto último se deba a un descuido legislativo que necesariamente habrá de ser subsanado dado que la garantía penal del principio de legalidad no permite que se imponga una pena no prevista para el delito. La pena principal de inhabilitación especial se contempla en la mayor parte de los casos de forma facultativa, recibiendo la consideración de grave cuando su duración supera los cinco años y menos grave en otro caso (art. 33. 2. d y 3. b) ${ }^{60}$. Como pena accesoria puede acompañar facultativamente a toda pena de prisión, coincidiendo entonces su duración con la de ésta (art. 33.6), pero será necesario en todo caso que los derechos afectados por la pena hubieran tenido relación directa con el delito cometido (arts. 55 y 56). Una vinculación que expresamente deberá determinarse y fundamentarse en la sentencia.

A pesar de lo dicho su contemplación como pena principal en los delitos sexuales y el juego de los artículos 54 a 56 hace que no quepa su imposición como pena accesoria en estos casos. Esto provoca que en un contexto como el de los delitos sexuales donde el uso de la pena de prisión, como dijimos, se encuentra ampliamente generalizado, la opción por atribuirle una función principal, que impide su aplicación como pena accesoria, nos conduzca a alguna situación paradójica desde el prisma del insistente endurecimiento del castigo para los delincuentes sexuales, dado que a tenor del artículo 192.3 su duración como pena principal podría oscilar sólo entre seis meses y seis años ${ }^{61}$. En este sen-

59 Hágase notar que en el artículo 189.7 tampoco se ordena al Ministerio Fiscal promover las acciones pertinentes con objeto de privar de la curatela, pero sí de la patria potestad, tutela, guarda o acogimiento familiar, en su caso, a quien comete el delito de omisión del deber de impedir el estado de prostitución o corrupción de un menor o persona con discapacidad necesitada de especial protección.

${ }^{60}$ Su extensión natural es de tres meses a veinte años (art. 40.1).

61 Podemos observar que en la concreción de la duración de esta pena influye la edad del menor respecto del cual se inhabilita al penado para el ejercicio de los mencionados derechos. Así en la sentencia de la Audiencia Provincial de las Islas Baleares (Sección 1 ${ }^{\mathrm{a}}$ ), $n^{\circ} .135 / 2013$, de 9 de diciembre, en un caso de doble agresión sexual por parte de su padre a una menor de 13 años se impuso esta pena por tiempo de seis meses que era el que restaba para que la menor alcanzase la mayoría de edad. 
tido y a modo de ejemplo podemos observar como el tutor de un menor de 16 años que comete un delito de abuso sexual del artículo 183.1 y 3 , siendo aquél la víctima, condenado a una pena de prisión de doce años, podrá como máximo recibir una pena de inhabilitación de seis años; mientras que si no existiera el artículo 192.3, en virtud del artículo 55, el juez podría aplicarle, sin embargo, la pena accesoria de inhabilitación especial para el ejercicio de los cargos de protección de menores durante doce años (art. 33.6).

Esta pena, según se establece en el artículo 46 desde un primer momento, priva al penado de los derechos inherentes a la patria potestad y supone la extinción de las demás instituciones (tutela, curatela, guarda y acogimiento) así como la incapacidad para obtener nombramiento para dichos cargos durante el tiempo de la condena. No obstante, como decíamos, la norma penal de la parte especial del CP en ocasiones limita sus efectos, bien mencionando únicamente algunas de las privaciones de derechos, bien previéndolas como alternativas (art. 233.1); llegando incluso en algún caso a acotar exactamente quien o quienes son las personas en relación con las cuales no cabría ejercer los derechos objeto de privación (art. 220.4) ${ }^{62}$. No es este el caso, sin embargo, de los delitos sexuales, en relación con los cuales el artículo 192.3 contempla en su integridad este tipo de inhabilitación especial (“...inhabilitación especial para el ejercicio de los derechos de patria potestad, tutela, curatela, guarda y acogimiento..." 63 ), lo que significa que el penado no podrá ejercer los derechos de patria potestad durante el tiempo de la condena, verá extinguidos todos los cargos de protección que tuviese y quedará incapacitado para ser nombrado para ese tipo de cargos durante el tiempo de duración de la pena.

El contenido de esta modalidad de inhabilitación especial en sí mismo considerado suscita algunos interrogantes. En esa línea se ha advertido cómo los distintos matices que se observa en la redacción de las referencias legales a esta pena no dejan claro en el caso de la patria potestad si la misma priva de su titularidad o sólo de su ejercicio ${ }^{64}$. Ciertamente a tenor de los artículos 39.b), que se refiere a "las inhabilitaciones especiales ... de los derechos de patria potestad, tutela, guarda o curatela", del 46, en el que se afirma que "la inhabilitación especial para el ejercicio de la patria potestad, tutela, curatela guarda o acogimiento, priva al penado de los derechos inherentes a la primera y supone la extinción de las demás ...", o del 192.3, a cuyo tenor "la pena de inhabilitación especial

${ }^{62}$ Se adentra en los problemas que ello ha planteado Guinarte Cabada, G., «La pena de inhabilitación especial de los derechos de patria potestad, tutela, guarda o curatela», cit., pp. 143-147.

${ }_{63}$ La referencia al acogimiento se introduce en la reforma del CP por LO 1/2015.

${ }^{64}$ Así Castillo Martínez, C. del C., La privación de la patria potestad. Criterios legales, doctrinales y judiciales, cit., p. 237. 
para el ejercicio de los derechos de patria potestad...", son comprensibles las dudas formuladas al respecto, pero éstas se despejarían incluso antes de la introducción de la pena de privación de la patria potestad; hecho, no obstante, que zanja cualquier polémica. El argumento en favor de considerar que la pena produce una afectación al ejercicio de los derechos de la patria potestad y no la pérdida de su titularidad, al margen de la apelación a la existencia de la pena de privación de la patria potestad, se encontraba ya en la propia dicción del precepto donde se prevé un distinto tratamiento de los efectos que la pena produce en la patria potestad y en el resto de los cargos mencionados, pues no tiene sentido que si la intención es causar el mismo efecto se diga en referencia a la patria potestad que se priva al penado de los derechos inherentes a la misma mientras que en relación con el resto de las instituciones de Derecho de familia mencionadas se declara su extinción ${ }^{65}$.

La delimitación de cuáles son exactamente los derechos inherentes a la patria potestad de cuyo ejercicio se ve privado el penado puede resultar, como vimos sucede con la pena de privación de la patria potestad, igualmente controvertida como consecuencia del hecho de que, al concebirse la patria potestad como una función, quien tiene su titularidad ostenta derechos-deberes o derechos-funciones, derechos que se le conceden para el cumplimiento de los deberes o la realización de sus funciones con las que se entremezclan los derechos de los protegidos. Problema que se agudiza en este caso en la medida en que al tener la pena una duración temporal el penado podría recuperar el ejercicio de la patria potestad antes de que se extinga la titularidad de la misma, resultando entonces especialmente contraproducente que la pena afectara a todos los derechos inherentes a la patria potestad, tal y como parece desprenderse del tenor literal del artículo 46. Una forma de prevenir males mayores para el restablecimiento de los vínculos entre padres e hijos podría ser dejar a salvo de esta pena el derecho-deber de velar por los hijos recogido en el artículo 110 del CC que civilmente pervive aunque el padre y la madre no ostenten la patria potestad, permitiéndoles mantener el derecho a solicitar información sobre las circunstancias en las que se encuentra el hijo. Incluso si consideramos que los hijos menores tienen derecho a relacionarse con sus progenitores aunque éstos no ejerzan la patria potestad (art. 160), el correlativo deber de los padres haría que la pena pudiera modularse para permitir algún régimen de comunicación y visitas entre ellos. Todo ello claro está dependiendo siempre del interés superior del menor ${ }^{66}$. A raíz de lo dicho cabría insistir una vez más en la necesidad de

${ }^{65}$ Recoge ambas posturas Guinarte Cabada, G., «La pena de inhabilitación especial de los derechos de patria potestad, tutela, guarda o curatela», cit., pp. 147-151, quien se manifiesta a favor de considerar que no se produce la pérdida de la titularidad de la patria potestad.

${ }_{66}$ Así también Guinarte Cabada, G., «La pena de inhabilitación especial de los derechos de patria potestad, tutela, guarda o curatela», cit., pp. 152-153. 
que el legislador concrete más el contenido de esta pena y, en tanto esto suceda, el juez descienda a pronunciarse sobre estos extremos.

También se ha discutido si la privación del ejercicio de los derechos de la patria potestad o la extinción del resto de cargos se ciñe a aquellos que se ejercen respecto de la víctima del delito por el que se pena o en cambio se podría extender a los que se ostentan respecto de otros menores ${ }^{67}$. La LO 15/2003 introdujo una disposición relacionada con esta cuestión que, en concordancia con la concreta finalidad preventiva de la pena, establece en el artículo 46, al igual que sucede con la pena de privación de la patria potestad, la posibilidad de que la pena se acuerde respecto de todos o de alguno de los menores que estén a cargo del penado, en atención a las circunstancias del caso; debiéndose dar por reproducido lo que en relación con aquella se comentó en este punto ${ }^{68}$.

No ofrece dudas, sin embargo, lo que implica esta pena para las instituciones protectoras distintas de la patria potestad, esto es, su extinción y la incapacidad para ser nombrado tutor, curador, guardador o acogedor durante el tiempo de la condena.

La privación del ejercicio de los derechos inherentes a la patria potestad y la incapacidad para obtener nombramiento para los cargos de tutor, curador, guardador y acogedor es temporal, no así la extinción de estos cargos que es definitiva. Una vez que ha transcurrido el tiempo de cumplimiento de la pena, ésta se extingue y, consiguientemente, se restablece de forma automática la responsabilidad parental, en tanto y cuan-

${ }^{67}$ El problema lo analiza la sentencia del Tribunal Supremo, Sala de lo Penal, $\mathrm{n}^{\circ}$. 568/2001 de 6 julio, a raíz de un recurso de casación interpuesto contra la sentencia de la Audiencia Provincial de Oviedo de 1 de febrero de 1999, en la que se condena a un hombre por un delito continuado de abuso sexual - tocamientos libidinosos en distintas partes del cuerpo, logrando que la menor le masturbase habitualmente- de una menor hija de su esposa, aplicándose, entre otras, la pena de inhabilitación especial para el ejercicio de la patria potestad respecto del hijo menor de edad común. Señala esta sentencia que el "acusado no era ni ascendiente, ni tutor, ni curador, ni guardador de hecho o de derecho de la víctima de los abusos sexuales que se juzgan, con lo que mal puede aplicarse aquí lo establecido en el artículo 192 del Código respecto a la imposición de la pena de privación de la patria potestad respecto a otro menor distinto de la propia víctima, pues de una interpretación, tanto literal, como lógica o finalista de ese precepto se infiere que su párrafo segundo, a que se contrae tal pena inhabilitadora, está íntimamente correlacionado con su apartado primero que se refiere exclusivamente al «menor o incapacitado» objeto de "agravio» y no a cualquier otro, ya que no en balde ese párrafo segundo emplea el adverbio «además» con clara indicación de que, a la mayor pena privativa de libertad que habrá de imponerse a esos ascendientes, tutores, etc., "puede» añadirse «razonadamente» la tan repetida pena de inhabilitación especial para el ejercicio de los derechos de la patria potestad. Por tanto, entendemos que la Sala de instancia incurrió en un evidente error «iuris» al privar de un derecho tan importante (y sagrado) como es el de la patria potestad a un padre respecto a un hijo menor (cuatro años) que nada tenía que ver con la actividad delictiva por la que aquél fue juzgado. Falta así el nexo causal entre los hechos y la pena de inhabilitación impuesta" (FJ. $2^{\circ}$ ).

68 Así Boldova Pasamar, M. A., «Penas privativas de derechos», cit., p. 66. 
do, obviamente, la persona respecto de la que se adoptó siga siendo menor o haya sido sometido a una patria potestad prorrogada ${ }^{69}$; de ahí que haya quien vea en esa pena por lo que se refiere en concreto al ejercicio de los derechos de la patria potestad una suspensión de éste ${ }^{70}$. Este restablecimiento de la patria potestad, la diversidad de los delitos sexuales y la no siempre condición de víctima del hijo hacen muy recomendable que en la vía penal se articulase la posibilidad de que durante la ejecución de esta pena se pudiera modificar, siempre en interés superior del menor, la decisión sobre la comunicación padre penado e hijo.

Una vez que se ha cumplido la pena la idoneidad de la persona para mantener la función protectora de la patria potestad será analizada exclusivamente en la jurisdicción civil; aconsejando la salvaguarda del interés superior que en caso de que se estime que ese padre no deba ejercer esas funciones se inicie el correspondiente proceso civil próxima la fecha de extinción de la pena. En este punto habría sido de gran utilidad que el CP, vía disposición adicional, instase al Ministerio Fiscal a analizar la situación y, en su caso, solicitar conforme a la normativa civil las medidas civiles pertinentes.

En relación con el resto de cargos la extinción de la pena hace que ésta deje de ser un obstáculo inexorable para ser nombrado para ejercerlos. No obstante, téngase presente, por ejemplo, que, de acuerdo con el $\mathrm{CC}$, la condena por cualquier delito que haga suponer que el condenado fundadamente no desempeñara bien la tutela - y por remisión la curatela- es causa que le inhabilita a tal fin $(\text { art. 243.4 })^{71}$.

\section{Breve apunte sobre su ejecución}

Como es sabido, la ejecución de la pena exige que la condena penal sea firme (arts. 3.1 CP y 998 LECr), debiéndose además observar en relación con estas penas una serie de disposiciones civiles. Al respecto el

69 Así Gutiérrez Castañeda, A., «Penas privativas y restrictivas de derechos», cit., p. 55. En opinión de Castillo Martínez, C. del C., La privación de la patria potestad. Criterios legales, doctrinales y judiciales, cit., p. 239, esto supone una vulneración del artículo 170 párrafo $2^{\circ}$ del CC, que al exigir la intervención judicial para la recuperación de la atribución de la patria potestad representaría una garantía necesaria para la salvaguarda del interés del menor. Lo que le lleva a considerar que el legislador penal ha incurrido en un descuido del principio de unidad y cohesión del ordenamiento jurídico. A mi juicio no advierte la autora que la naturaleza penal de esta inhabilitación, que no privación de la patria potestad, y, consiguientemente, sus fines afectan a la resolución de esta cuestión.

70 Así Messía de la Cerda Ballesteros, J. A., «La privación de la patria potestad por sentencia penal», cit., p. 6.

${ }_{71}$ Ello es así excepto si los tutores han sido designados en las disposiciones de última voluntad de los padres cuando tal circunstancia fuera conocida por éstos en el momento de hacer la designación, salvo que el juez, en resolución motivada, disponga otra cosa en beneficio del menor o del incapacitado (art. 246 CC). 
CC señala que las resoluciones judiciales sobre los cargos tutelares y de curatela habrán de inscribirse en el Registro Civil en virtud de testimonio remitido al encargado del Registro Civil (arts. 218 y 219). Asimismo la Ley 20/2011, de 21 de julio, del Registro Civil establece que son hechos inscribibles en este registro las relaciones paterno-filiales, la tutela, la curatela, las demás representaciones legales y sus modificaciones (art. $4.9^{\mathrm{a}}$ y $\left.11^{\mathrm{a}}\right)^{72}$; especificándose en el artículo 71 , por lo que aquí concierne, que se inscribirá la extinción, la privación, la suspensión y la rehabilitación de la patria potestad y de las figuras similares o asimilables a ella de Derecho civil propio de las Comunidades Autónomas - no se recoge una disposición de equivalente tenor para el resto de instituciones protectoras-. Consiguientemente en la medida en que estas penas afectan a esas instituciones se habrá de facilitar por parte del órgano encargado de la ejecución de la condena penal a los encargados del Registro Civil los datos e información necesarios para la práctica de aquéllas (art. 14). No obstante, dada la lentitud de la Administración de Justicia, conviene observar que la ley registral también obliga a promover sin demora la inscripción a aquellos a quienes se refiere el hecho inscribible, sus herederos o representantes legales (art. 42). Los títulos necesarios para practicar la inscripción, entre los que se encuentran las resoluciones judiciales firmes (art. 27.2), también pueden ser presentados por terceros en la medida en que toda persona tiene derecho a promover la inscripción de determinados hechos y actos dirigidos a la protección de los menores (art. 11. i). Las causas de privación o suspensión de la patria potestad, por otra parte, son datos sometidos a un régimen de publicidad restringida (art. 83.1. d) ${ }^{73}$.

El hecho de que la pena de privación de la patria potestad sea definitiva hace que no sea necesario comunicar al Registro Civil que la pena ha dejado de tener efectos; lo que acontecería, en otro caso, como consecuencia de que el menor ya no fuese a estar sujeto a la patria potestad sea porque se ha producido su emancipación sea porque ha cumplido la mayoría de edad, sea porque ha desaparecido la causa que motivo la prórroga de la patria potestad. En cambio la duración temporal de la pena de inhabilitación especial para el ejercicio de las funciones de protección de los menores sí hace que sea necesaria la modificación de la inscripción registral.

A la luz de los efectos de ambas penas desde el prisma de la protección de los menores, el CP incentiva la coordinación entre la jurisdicción penal y la civil con la previsión, en la disposición adicional segunda de

72 Señala el artículo 71.1 que los hechos que afecten a las relaciones paterno-filiales se inscribirán en el registro individual de la persona sujeta a patria potestad y en el de su progenitor o en los de sus progenitores.

${ }_{73}$ Sólo el inscrito o sus representantes legales pueden acceder o autorizar a terceras personas la publicidad de los asientos (art. 84). 
la LO 10/1995, modificada por la LO 5/2010, de la comunicación judicial inmediata de la aplicación de estas penas a la entidad pública que en el respectivo territorio tenga encomendada la protección de los menores y al Ministerio Fiscal para que actúe de conformidad con sus respectivas competencias. Obviamente este tipo de actuación deviene innecesaria cuando el menor sigue sometido a la patria potestad del otro padre siempre y cuando el ejercicio de ésta por éste sea pleno.

\section{Las penas de inhabilitación especial para empleo o cargo público o ejercicio de la profesión u oficio y para cualquier profesión u oficio que conlleve contacto con menores de edad}

El artículo 192.3 del CP prevé para los condenados por delitos contra la libertad e indemnidad sexuales otra pena facultativa, la pena de inhabilitación para empleo o cargo público o ejercicio de la profesión u oficio, a la que asigna el mismo marco penal de duración que a la inhabilitación especial anteriormente señalada, es decir, de seis meses a seis años. Esta pena parece ser el resultado de la combinación legislativa de parte de los objetos sobre los que recaen dos penas de inhabilitación especial legalmente configuradas como penas independientes: la pena de inhabilitación para empleo o cargo público y la pena de inhabilitación especial para profesión, oficio, industria o comercio o cualquier otro derecho; pues si bien el legislador no ha precisado si se trata de una inhabilitación especial o absoluta, y ciertamente al menos el empleo o cargo público puede verse afectado por ambas, su duración no se corresponde con la gravedad de una pena de inhabilitación absoluta. En consecuencia ha de entenderse que la inhabilitación para el empleo o cargo público priva al penado de forma definitiva del empleo o cargo público sobre el que recayese, aunque fuese electivo, de los honores que le sean anejos y además comporta la incapacidad del penado durante el tiempo de la pena para obtener los mismos o cualesquiera otros análogos (art. 42); y la inhabilitación especial para profesión u oficio priva al penado de la facultad de ejercer la profesión u oficio durante el tiempo de la condena (art. 45). Así las cosas, y de forma muy resumida, nos encontramos ante una pena que afecta principalmente a la ocupación laboral de la persona, medie o no vinculación con la Administración pública.

Esta pena presenta un marcado carácter preventivo enfocado a evitar la continuidad delictiva que pudiera tener lugar o verse favorecida a raíz del desempeño de la actividad laboral. De ahí que se considere que no necesariamente la pena tiene que comportar una afectación de toda su actividad laboral, pudiendo el juez en la sentencia precisar exactamente los aspectos de la misma que se ven afectados por la pena; resultando así la pena más acorde con el principio resocializador. La finalidad perse- 
guida, no obstante, se puede frustrar de seguirse una interpretación de la norma ajustada a su literalidad dado que la afectación al empleo o cargo público y al ejercicio de la profesión u oficio se disponen de forma alternativa, pudiéndonos encontrar ante situaciones tan absurdas como que a un profesor - funcionario público- condenado por el abuso sexual de un menor de 17 años se le inhabilite para ese empleo público pero no para el ejercicio de la profesión de profesor.

La aplicación de esta pena, como pena principal, no exige, a diferencia de lo que sucede cuando se aplica como pena accesoria, que exista una conexión directa entre el delito cometido y los derechos afectados por la pena (art. 56). Ello unido al hecho de que no es una pena imperativa por ley hace que el juez en el momento de la determinación de la pena no se vea limitado en el ejercicio de esta función más que por los criterios de individualización de la pena, incluidos obviamente los fines de las penas.

La pena de inhabilitación especial para cualquier profesión u oficio, sea o no retribuido, que conlleve contacto regular y directo con menores de edad puede concebirse como otra modalidad de la pena de inhabilitación especial no obstante hallarse silenciada en los preceptos de la parte general de nuestro CP. Su incorporación al sistema de penas se produjo en la reforma del CP por la LO 1/2015 con motivo de la transposición de la Directiva 93/2011/UE — si bien también el Convenio de Lanzarote, como vimos, contempla la posibilidad de adoptar medidas de ese tipo-. Se ahonda así en una vía abierta ya en el seno de la UE años antes a través de la Decisión marco 2004/68/JAI del Consejo, de 22 de diciembre de 2003, relativa a la lucha contra la explotación sexual de los niños y la pornografía infantil, que había ordenado a los Estados la adopción de medidas para poder, en su caso, inhabilitar, con carácter temporal o permanente, para el ejercicio de actividades profesionales a los condenados por determinados delitos sexuales en perjuicio de menores, aunque circunscrita ésta a aquellas que supusiesen el cuidado de niños (art. 5.3).

Esta pena de inhabilitación es objeto de regulación en el artículo 192.3 del CP, dentro del título dedicado a los delitos contra la libertad e indemnidad sexual. A tener del mismo esta pena se presenta como una pena principal, imperativamente por ley, vinculada a un determinado grupo de delitos sexuales. En concreto los delitos del capítulo II bis (de abusos y agresiones sexuales a menores de dieciséis años) y los del capítulo V (delitos relativos a la prostitución y a la explotación sexual y corrupción de menores). En atención al fin especialmente preventivo que se persigue con esta pena es difícil comprender el motivo de esta circunscripción que deja al margen a los responsables de otros delitos sexuales en perjuicio de menores como son los delitos de abuso y agresión sexual a menores de 16 y 17 años — contra los que también pretende luchar la Directiva-y los delitos de acoso, exhibicionismo y provocación sexual; máxime cuando quedan afectados también por la pena los condenados 
por delitos relativos a la prostitución de adultos. Se produce así un distanciamiento entre nuestra regulación legal y la Directiva, no obstante, de posible solución por vía interpretativa, como veremos. Pero no es el único, dado que, como vimos, la Directiva no ordena la imposición en todo caso de una inhabilitación de este tipo, sino que lo que persigue es que tal posibilidad exista con la finalidad de evitar la reincidencia, pudiendo entenderse entonces que un criterio para la aplicación de la misma fuese la peligrosidad de reincidencia específica.

Por lo que se refiere a su contenido, a tenor de lo dispuesto en el artículo 192.3 simplemente podemos saber que esta pena de inhabilitación especial incide sobre cualquier profesión u oficio, retribuido o no, que conlleve contacto regular y directo con menores de edad; no siendo objeto de ulterior aclaración ninguno de esos aspectos. Los términos "profesión u oficio", que se suelen definir, por referencia al ejercicio de una actividad profesional privada, necesariamente han de adquirir un nuevo significado a la luz de la directiva, que ordena la inhabilitación para actividades al menos profesionales, sin distinción ulterior entre el ámbito público y el privado, resultando comprensivos de cualquier actividad profesional, sea pública o privada. En otro caso, nos encontraríamos ante una manifiesta discriminación por la ley penal de los responsables penales en función de si son o no empleados públicos, que privilegiaría a estos últimos.

La adjetivación de esa profesión u oficio como de retribuida o no seguramente responda al propósito de que la inhabilitación alcance a las actividades de voluntariado o benéficas —recuérdese que la Directiva utilizaba el término más amplio de "actividades"-, pero se trata de una vía igualmente confusa si tenemos presente que el ejercicio de la profesión, del que puede ser sinónimo el oficio, implica por definición la obtención de una retribución; lo que permitiría mantener viva la duda sobre si efectivamente las actividades de voluntariado o de otro tipo se ven o no afectadas por esta modalidad de inhabilitación ${ }^{74}$. La taxatividad que el principio de legalidad penal exige en la descripción de la pena y el fin pretendido con este tipo de medida se hubiese satisfecho en mejor medida si el legislador hubiera añadido una referencia expresa a las actividades organizadas junto a la profesión y el oficio.

La casuística de las profesiones y oficios hace comprensible que el texto de la ley utilice para acotar aquellos afectados por la pena una expresión necesitada de una ulterior delimitación por parte de los órganos judiciales so pena de mermar la seguridad jurídica. La pena sólo incide en las profesiones y oficios que conlleven contacto regular y directo con

${ }^{74}$ Entre las actividades de otro tipo distinto a las profesionales y a las de voluntariado se encuentran, por ejemplo, múltiples funciones que las personas pueden desempeñar en una confesión religiosa y que les permite el contacto regular y directo con menores. 
menores de edad, esto es, de acuerdo con el significado lingüístico de los adverbios "regular" y "directo", un contacto de forma normal o habitual y sin intermediario; lo que no necesariamente exigiría que el penado y los menores estuviesen presentes físicamente en el mismo espacio. Precisión que consideramos interesante hacer a la luz del gran desarrollo de las TIC, la generalización de su utilización entre los menores y el papel que han adquirido en el proceso de socialización de éstos, así como por el uso de las TIC en la comisión de delitos. No obstante lo dicho, en un intento de reequilibrar los fines que se asocian a esta pena, por su efecto desocializador para el penado, con la reinserción social de las personas a través del trabajo, parece aconsejable realizar una interpretación restrictiva del alcance resultante de una mera interpretación de la norma ajustada a su literalidad, circunscribiendo esas profesiones u oficio a aquellas que por la propia naturaleza del oficio o profesión conllevan de forma innata ese contacto regular y directo; de manera que no se viesen afectadas aquellas que estando destinadas a un público general, pueden dar ocasión a un contacto regular y directo con menores. Tal sería el caso obvio de los maestros y profesores de educación infantil, primaria, secundaria y bachillerato; de los cuidadores de niños; de los pedíatras; de los psicólogos infantiles; de los monitores de actividades para menores, por ejemplo. Ahora bien, y así lo avalan los conceptos "directo" y "regular", la finalidad de esta pena exige al mismo tiempo que la precisión del oficio o profesión no se realice a partir de una consideración abstracta del mismo (por ejemplo, vendedor, conductor de transporte de personas, entrenador) sino en atención a una mayor especificidad por referencia a su desempeño en relación con los menores. En este sentido podríamos entender que un conductor de transportes de personas condenado a esta pena podría seguir desempeñando su profesión, pero no prestar un servicio de transporte escolar; o que un vendedor siguiese con su actividad salvo, por ejemplo, en un kiosco exclusivamente de golosinas. La casuística, como decíamos, es tan grande, que pudiera ser muy positivo que por vía reglamentaria se elaborase una lista, aunque fuese meramente ejemplificadora, de las profesiones u oficios afectados, para su facilitación al penado en el momento de la condena en aras de que pudiera orientar con certeza su actividad.

El citado precepto contiene también reglas propias relativas a su duración y aplicación. Esta inhabilitación tiene que durar entre tres y cinco años más que la pena privativa de libertad impuesta en la sentencia; pero si la pena impuesta no fuese de prisión su marco penal es de dos a diez años. La concreción exacta de su duración se ha de realizar atendiendo proporcionalmente a dos criterios básicos de determinación de la pena como son la gravedad del delito y las circunstancias del sujeto, pero tam- 
bién al número de delitos cometidos ${ }^{75}$; criterio del que cabría desprenderse que aunque el sujeto hubiese sido condenado en esa sentencia por una pluralidad de delitos sexuales afectados por esta inhabilitación sólo se impondría una pena de inhabilitación especial de este tipo.

El tratamiento autónomo de esta modalidad de inhabilitación especial, que hasta entonces podría haberse impuesto igualmente al amparo de una interpretación restrictiva del contenido de la pena de inhabilitación especial para el ejercicio de la profesión u oficio genérica prevista también pero de forma facultativa y para cualquier delito sexual en ese mismo número, como hemos visto, no tiene porqué significar necesariamente, a nuestro juicio, un desplazamiento de la pena genérica en el sentido de que ésta ya no pueda concretarse en una inhabilitación para el ejercicio de una profesión u oficio que conlleve ese contacto con menores. Es más, la pervivencia de esta posibilidad es obligada para no infringir la Directiva de referencia que, como dijimos, ordena este tipo de medida en relación con todos los delitos sexuales cuya incriminación demanda ${ }^{76}$. Ni tampoco existe razón legal alguna para entender que ambas penas no se pueden aplicar conjuntamente siempre y cuando, como es lógico, su contenido sea diferente ${ }^{77}$.

El efecto principal que se persigue con esta pena, como es el de evitar que estos condenados entren en contacto con los menores, se potencia aún más a través de una nueva medida preventiva no penal restrictiva del ejercicio de profesiones o actividades que impliquen contacto habitual con menores a la que nos referiremos más adelante.

\section{Las penas de alejamiento}

Los delitos contra la libertad e indemnidad sexual forman parte del grupo de delitos a los que se dirige la cláusula penológica del artículo 57, objeto ya de cinco redacciones. Esta cláusula disciplina la aplicación de las denominadas genéricamente penas de alejamiento, esto es, la prohibición de residir en lugares determinados o de acudir a ellos, la prohibición de aproximarse a la víctima u otras personas y la prohibición de comunicarse con la víctima u otras personas, (arts. 39 f, g y h y 48); difuminando, a tenor de los criterios de aplicación de estas penas, la clara distinción teórica entre el Derecho penal de la culpabilidad y el Derecho penal de la peligrosidad en aras de dispensar una mayor protección a

75 Podría, no obstante, verse en esta apelación al número de delitos una conexión con la peligrosidad criminal del sujeto en sintonía con el cariz con el que se propone esta medida en la Directiva.

${ }^{76}$ Nótese que de ser así la pena tendría una duración de seis meses a seis años.

77 Así Salat Paisal, M., «Las consecuencias sancionadoras aplicables a los delincuentes sexuales tras las últimas reformas legislativas», cit., p. 322. 
las víctimas del delito frente a nuevos ataques procedentes del penado. Pero también para satisfacer otros intereses de las víctimas entre los que podría encontrarse la salvaguarda de su propia tranquilidad que pudiera verse alterada ante un mero encuentro o contacto con el penado ${ }^{78}$. Así se desprendería de la previsión de la gravedad de los hechos y del peligro representado por el delincuente como criterios alternativos de aplicación de estas penas y no acumulativos y del hecho de que cuando la víctima del delito - grave o menos grave- pertenece al círculo de personas que sufren la violencia doméstica y la violencia de género la prohibición de aproximación es imperativa por ley ${ }^{79}$.

Los daños que los delitos sexuales pueden causar a las víctimas más allá de la afectación a la libertad e indemnidades sexuales y el hecho de que sea frecuente que el penado sea un conocido de la víctima hacen que estas penas sean por su contenido especialmente interesantes. La privación del derecho a residir en determinados lugares o acudir a ellos impide al penado residir o acudir al lugar de comisión del delito o a aquel en que resida la víctima o su familia si fueran distintos; la prohibición de aproximarse a la víctima o a aquellos de sus familiares u otras personas que determine el juez impide al penado acercarse a ellos, en cualquier lugar donde se encuentren, así como acercarse a su domicilio, a sus lugares de trabajo y a cualquier otro que sea frecuentado por ellos ${ }^{80}$; la prohibición de comunicarse con la víctima o con aquellos de sus familiares u otras personas que determine el juez impide al penado establecer con ellas, por cualquier medio de comunicación o medio informático o telemático, contacto escrito, verbal o visual.

${ }^{78}$ A modo de ejemplo, la STS, $n^{\circ} .1463 / 2000$, de 22 de septiembre (FJ. $2^{\circ}$ ), considera acertada la aplicación de estas prohibiciones en base al siguiente razonamiento del Ministerio Fiscal: "a causa de estos hechos (delito de estupro continuado y agresión sexual) la menor que había sido objeto de rumores y comentarios en el ámbito escolar y en su entorno, sufre sentimiento de indefensión, angustia y fuerte ansiedad, dificultad de concentración y un estado de temor", añadiendo que dada la dilatación del tiempo de la relación entre acusado y víctima, y la juventud de ésta, su previsible encuentro afectaría a la víctima, aunque no llegara a ser objeto de nuevos actos ilícitos.

${ }^{79}$ La víctima del delito tiene que ser el cónyuge o excónyuge del penado, la persona que esté o haya estado ligada a éste por una análoga relación de afectividad aun sin convivencia, los descendientes, ascendientes o hermanos por naturaleza, adopción o afinidad, propios del penado o del cónyuge o conviviente, los menores o personas con discapacidad necesitadas de especial protección que convivan con el penado o que se hallen sujetos a la potestad, tutela, curatela, acogimiento o guarda de hecho de su cónyuge o conviviente, la persona amparada en cualquier otra relación por la que se encuentre integrada en el núcleo de la convivencia familiar del penado, las personas que por su especial vulnerabilidad se encuentran sometidas a su custodia o guarda en centros públicos o privados.

80 A raíz de la reforma del CP por la LO 15/2003 se amplió su contenido con la mirada especialmente puesta en la problemática de la violencia doméstica, de forma que esta pena también comporta la suspensión, respecto de los hijos, del régimen de visitas, comunicación y estancia que, en su caso, se hubiere reconocido en sentencia civil. 
A tenor del artículo 57.1 y 2 la duración máxima de cualquiera de estas penas en los delitos sexuales, que o bien son graves o bien menos graves, puede llegar a los diez años si el delito es grave o hasta los cinco si fuera menos grave. No obstante, en realidad su duración puede ser mayor si tenemos presente la vía que ha articulado el legislador para evitar que en caso de que se aplicasen conjuntamente con una pena de prisión, al ser consideradas penas de cumplimiento simultáneo con la pena de prisión, sus efectos quedasen mayormente absorbidos por ésta. En estos casos el tiempo de duración de las penas de alejamiento se concretará por un tiempo superior de entre uno y diez años o de entre uno a cinco años a la pena de prisión impuesta por un delito sexual grave o menos grave respectivamente.

\section{La medida de seguridad de libertad vigilada}

La tendencia existente hacia el incremento de la duración temporal del sometimiento del responsable penal al sistema de respuesta penal ha conducido en un sistema penal como el nuestro, en el que la pena de prisión ya de por sí presenta una larga duración, no sólo formal sino también a la luz de su cumplimiento en sentido material, a la articulación de la medida de seguridad de libertad vigilada como una vía adicional de respuesta penal para los responsables penales de determinados delitos fundamentada en su peligrosidad criminal en defensa de la libertad y seguridad del resto de los ciudadanos ${ }^{81}$, cuyo cumplimiento se proyecta de forma inmediatamente sucesivo a la extinción de la pena de prisión ${ }^{82}$. Así lo disciplinó, tras renunciarse a la introducción de la más

81 Vid., Sanz Morán, A. J., «La nueva medida de libertad vigilada: reflexión políticocriminal», en Muñoz Conde, F./ Lorenzo Salgado, J. M./ Ferré Olivé, J. C./ Cortés Bechiarelli, E./ Núñez Paz, M. A., (dir.), Un Derecho penal comprometido: libro homenaje al Prof. Dr. Gerardo Landrove Díaz, Ed. Tirant lo Blanch, Valencia, 2011, pp. 997-1028; Benítez Ortúzar, I. F., "La nueva "medida de seguridad" de "libertad vigilada" aplicable al sujeto imputable tras el cumplimiento de la pena privativa de libertad. La admisión de los postulados del "Derecho penal del enemigo" por la LO 5/2010», en CPC, 2011, n. 103, pp. 95132; o Salat Paisal, M., La respuesta jurídico-penal a los delincuentes imputables peligrosos: especial referencia a la libertad vigilada, cit. pp. 355-393.

Obsérvese también que algunas voces se habían pronunciado a favor de introducir una libertad vigilada bajo el ropaje de pena antes de esta reforma para los delincuentes sexuales con pronóstico de reincidencia alto; así Mena, J. M., «¿Qué hacer con los agresores sexuales reincidentes?», en ¿Qué hacer con los delincuentes sexuales reincidentes?, Ed. Fundación Víctor Grífols i Lucas, 2009, p. 41, quien marcaba su duración en función del pronóstico de reincidencia e insistía en que ni podía aplicarse de forma burocrática ni de forma disciplinada.

82 En otros sistemas jurídicos se ha llegado incluso a prever una medida de seguridad privativa de libertad. En el caso concreto de Alemania esa medida de seguridad se conoce como custodia de seguridad y su configuración en las últimas décadas ha tenido una agitada vida jurídica. Vid., por ejemplo, Cano Paños, M. A., «El marco jurídico y criminológico de la custodia de seguridad (Sicherungsverwahrung) en el Derecho penal alemán», 
gravosa medida de seguridad de custodia de seguridad prevista en los anteproyectos de reforma del CP de julio y octubre de 2012, que tantas críticas doctrinales suscitaron en nuestro país ${ }^{83}$, en un primer momento la LO 5/2010 precisamente para los delincuentes sexuales, equiparados también en este punto a los terroristas ${ }^{84}$, aunque de los datos disponibles sobre la delincuencia sexual no se advirtiese un riesgo necesariamente elevado de reincidencia específicamente sexual ${ }^{85}$. Esta vía excepcional, determinada por la tipología delictiva, y de posible aceptación bajo determinados presupuestos relativos a la grave peligrosidad criminal presente en el condenado, el respeto de los principios básicos del Derecho penal y muy en particular la dignidad personal ${ }^{86}$, se extendería, no obstante, a otro tipo de delincuencia (homicidios y violencia de género y doméstica) en la reforma del CP por LO 1/2015 ${ }^{87}$, confirmándose los temores de la generalización de la excepcionalidad que siempre rodean la adopción legislativa de medidas excepcionales.

En el concreto ámbito de la delincuencia sexual, y de conformidad con los artículos 106.2 y 192.1, la medida de seguridad de libertad vigilada postpenitenciaria, no obstante afirmar el legislador su previsión para supuestos de especial gravedad en los que el efecto rehabilitador de la pena se ve dificultado (Preámbulo IV de la LO 5/2010), está prevista de forma generalizada para el responsable penal de cualquier delito contra la libertad e indemnidad sexual y no sólo para los que presentan un riesgo moderado o alto de reiteración delictiva ${ }^{88}$. No estando tampoco

en $C P C, 2007, \mathrm{n}^{\circ} .91$, pp. 205-250; Borja Jiménez, E., «Custodia de seguridad, peligrosidad postcondena y libertad en el estado democrático de la era de la globalización: una cuestión de límites», en $R G D P, 2012$, nº 18 , pp. 24-47.

83 Vid. Álvarez García, F. J., (dir.), Estudio crítico sobre el anteproyecto de reforma penal de 2012, Ed. Tirant lo Blanch, Valencia, 2013, pp. 395-484.

84 Vid. tras la LO 2/2015, de 30 de marzo, por la que se modifica la LO 10/1995, de 23 de noviembre, del CP, en materia de delitos de terrorismo, el artículo 579 bis.

85 Vid. una reseña respecto del conocimiento empírico sobre la reincidencia de los delincuentes sexuales en González Tascón, M. M., «El mecanismo de respuesta penal frente al delincuente sexual imputable: del favorecimiento de la ideología inocuizadora en detrimento del tratamiento resocializador», en Roca Agapito, L. (dir.), Un sistema de sanciones penales para el siglo XXI, Ed. Tirant Lo Blanch, Valencia, 2019, en prensa.

${ }_{86}$ Resaltados éstos por Zugaldía Espinar, J. M., «Medidas de seguridad complementarias y acumulativas para autores peligrosos tras el cumplimiento de la pena», en $R D P C r U$ NED, 2009, n. 1, pp. 204- 206.

87 Concretamente la medida de seguridad de libertad vigilada, acumulada y postpenitenciaria, se extendió en la reforma del CP por LO 1/2015, aunque sólo de forma facultativa, a los responsables penales de los delitos de homicidio y asesinato (art. 140 bis), de los delitos de lesiones cuando la víctima es alguna de las personas víctimas de violencia de género y violencia doméstica o asimilada (art. 156 ter) y del delito de violencia habitual en el ámbito doméstico o asimilado (art. 173.2).

88 Una categoría concreta de delincuente sexual para el que esta medida se viene considerado adecuada es la de los psicópatas sexuales, dado que de forma general presentan un elevado riesgo de reincidencia. Al respecto vid. Navarro Frías, I., «Psicopatía y medidas de seguridad: el caso de los psicópatas sexuales y la libertad vigilada tras la última refor- 
circunscrita a los delincuentes sexuales en sentido estricto. De forma que sólo en aquellos contados casos en los que la pena típica es la pena de prisión en alternativa a la pena de multa y el juez opta por ésta quedaría desplazado el planteamiento de la medida de seguridad. La gravedad del delito, por su parte, es igualmente irrelevante salvo que se combine con la condición de delincuente primario del responsable de un único delito.

Estos problemas se agravaban aún más desde el momento en que la peligrosidad criminal que se pretende controlar o anular a través de esta medida de seguridad no deriva siempre de un específico pronóstico individual de peligrosidad criminal de naturaleza sexual, sino de una presunción iuris et de iure en virtud de la cual sencillamente es un delincuente sexual peligroso quien ha cometido un delito contra la libertad e indemnidad sexual, grave o menos grave, no siendo primario. Así las cosas hemos asistido a la configuración legal de una medida de seguridad al margen del fundamento y los principios que rigen el Derecho de medidas de seguridad, entre ellos el principio de necesidad, posiblemente en atención únicamente a dos de las variables que, según las investigaciones criminológicas, apuntarían hacia una mayor peligrosidad criminal de estos delincuentes: el cumplimiento de condenas por más de un delito sexual y la existencia de antecedentes penales ${ }^{89}$. Y ello posiblemente en realidad sólo para producir un efecto simbólico en la sociedad desde el momento en que, como explicaremos, próximo el momento de cumplimiento de la medida se abre un procedimiento para su ratificación que está condicionada por su necesidad en el caso individual concreto. Sin olvidar además que su finalidad se puede perfectamente desarrollar en un momento anterior en el marco de la suspensión condicional de la ejecución del resto de la pena, sin necesidad, por tanto, de prolongar la restricción de derechos de estos penados.

El carácter primario del delincuente sexual reorienta la aplicación de esta medida de seguridad al sistema de medidas, pero sólo si éste ha cometido un único delito, que además ha de ser menos grave. Ante esta última hipótesis la decisión de imponer o no esa medida de seguridad es del juez, quien, según dice el artículo 192.1, atenderá a la menor peligrosidad del autor. La forma de expresión utilizada por el legislador, de la que se deriva que la medida de seguridad de libertad vigilada no se impondrá en el caso de condenados con menor peligrosidad, insiste, como vemos, en el carácter peligroso del delincuente sexual, si bien en este caso el establecimiento de una presunción legal favorable a considerar al delincuente sexual como un sujeto peligroso criminalmente merecedor

ma del Código Penal», en $C P C, 2011, \mathrm{n}^{\circ} .105$, pp. 132-158, quien, no obstante, considera que a tenor de su contenido no va a ser capaz de neutralizar la peligrosidad criminal de los psicópatas en los casos más graves.

${ }_{89}$ Así Navarro Frías, I., «Psicopatía y medidas de seguridad: el caso de los psicópatas sexuales y la libertad vigilada tras la última reforma del Código Penal», cit., p. 129. 
de una reacción penal más prolongada puede ser contradicho por el juicio individualizado de comportamiento futuro ${ }^{90}$.

La determinación de la gravedad del delito se realiza con arreglo a lo dispuesto en los artículos 13 y 33 del CP. Mayor complicación representa delimitar qué se entiende en este contexto por delincuente primario dado que la ley no realiza al respecto mayor precisión. Esa expresión suele considerarse equivalente al hecho de delinquir por primera vez y, consiguientemente, una primera interpretación sistemática de la norma con lo dispuesto en el artículo 80.1.2.1 ${ }^{\mathrm{a}}$, nos podría llevar a entender que tal condición únicamente no se da en quién ha cometido un delito doloso grave o menos grave cuyos antecedentes penales no han podido ser cancelados ${ }^{91}$. Pero ésta debe complementarse además con una interpretación finalista de la ley que atendiendo a su objetivo de reforzar la protección de la ciudadanía frente al comportamiento sexual penalmente relevante exija que el sujeto al que se imponga esta medida de seguridad haya sido condenado asimismo anteriormente no por cualquier delito sino por un delito contra la libertad e indemnidad sexual.

Adentrándonos ya en el contenido concreto de esta medida de seguridad, se desprende del artículo 106.1, que la misma comporta el sometimiento de la persona a un control judicial a través de la observancia por su parte de alguna o algunas de las obligaciones, prohibiciones, deberes o reglas de conducta, que el juez establezca de entre las previstas en la ley ${ }^{92}$. Éstas son en concreto las siguientes: la obligación de estar siempre localizable mediante aparatos electrónicos que permitan su seguimiento permanente; la obligación de presentarse periódicamente en el lugar que el juez o Tribunal establezca; la obligación de comunicar inmediatamente, en el plazo máximo y por el medio que el juez o tribunal señale a tal efecto, cada cambio del lugar de residencia o del lugar o puesto de trabajo; la prohibición de ausentarse del lugar donde resida o de un determinado territorio sin autorización del juez o tribunal; la prohibición de aproximarse a la víctima, o a aquellos de sus familiares u otras personas que determine el juez o tribunal; la prohibición de comunicarse con la

90 Navarro Frías, I., «Psicopatía y medidas de seguridad: el caso de los psicópatas sexuales y la libertad vigilada tras la última reforma del Código Penal», cit., p. 129.

${ }_{91}$ Así Marco Francia, M. P., Los agresores sexuales de menores: aspectos criminológicos y tratamiento jurídico penal, 2015, p. 384. Tesis doctoral disponible en https://ruidera.uclm. es/xmlui/bitstream/handle/10578/7171/TESIS\%20Marco\%20Francia.pdf? sequence=1 (consulta 24-05-2017).

${ }_{92}$ Nótese que muchas de estas obligaciones eran medidas de seguridad autónomas antes de la reforma citada y están presentes en el marco de las medidas de prueba, llegando incluso en algún caso a constituir penas autónomas.

Ampliamente sobre el contenido de esta medida Armaza Armaza, E. J., El tratamiento penal del delincuente imputable peligroso, Tesis doctoral leída en la Universidad del País Vasco, 2011, pp. 322-344 —disponible en http://hdl.handle.net/10810/12180 (consulta 1306-2016) - o El tratamiento penal del delincuente imputable peligroso, Ed. Comares, Granada, 2013. 
víctima, o con aquellos de sus familiares u otras personas que determine el juez o tribunal; la prohibición de acudir a determinados territorios, lugares o establecimientos; la prohibición de residir en determinados lugares; la prohibición de desempeñar determinadas actividades que puedan ofrecerle o facilitarle la ocasión para cometer hechos delictivos de similar naturaleza; la obligación de participar en programas formativos, laborales, culturales, de educación sexual u otros similares; y la obligación de seguir tratamiento médico externo o de someterse a un control médico periódico (art. 106.1) ${ }^{93}$. De entre todas estas obligaciones, en su inmensa mayoría enlazadas a medidas probatorias e incluso algunas constitutivas de penas, las relativas al seguimiento a un tratamiento médico externo o al sometimiento a un control médico periódico, como podría ser, por ejemplo, un tratamiento hormonal para reducir el impulso sexual ${ }^{94}$, resultan especialmente problemáticas desde el prisma del principio de autonomía de la voluntad del paciente dado que en este contexto se aplican a sujetos plenamente responsables ${ }^{95}$. Ahora bien, a la luz de la previsión contenida en el artículo 100.3 lo cierto es que no existe un refuerzo normativo del cumplimiento de la obligación de seguir un tratamiento médico, dado que la negativa a someterse a éste o a continuar con el mismo, en caso de que previamente se haya consentido, sólo faculta al juez para acordar la sustitución de esa obligación. La participación en programas resocializadores asimismo no está supeditada en estos casos al consentimiento del penado a diferencia de lo que sucede cuando forma parte del tratamiento penitenciario.

La duración de esta medida se establece en función de la gravedad del delito o delitos cometidos. Siempre que alguno de los delitos sea grave, su duración oscilará entre cinco y diez años; en otro caso, esto es, si se trata de uno o más delitos menos graves, será de uno a cinco años.

Como se habrá notado ya, la medida de seguridad de libertad vigilada ofrece al órgano sentenciador la posibilidad de configurar una supervisión temporal del penado de muy diferente intensidad en atención a su peligrosidad criminal y necesidades específicas mediante la combinación de opciones de muy diversa naturaleza (preventivas, resocializadoras, orientadas a la satisfacción de los intereses de las víctimas, de mero con-

${ }_{93}$ De gran interés es la propuesta que hace Zugaldía Espinar, J. M., «Medidas de seguridad complementarias y acumulativas para autores peligrosos tras el cumplimiento de la pena», cit., p. 209, relativa a que se articulase también en el marco de la libertad vigilada el derecho a recibir asistencia postpenitenciaria recogido en los artículos 73 a 75 de la LOGP, que va mucho más allá que los programas de tratamiento.

${ }_{94}$ Armaza Armaza, E. J., El tratamiento penal del delincuente imputable peligroso, cit., pp. 333-334.

${ }_{95}$ En este sentido Navarro Frías, I., «Psicopatía y medidas de seguridad: el caso de los psicópatas sexuales y la libertad vigilada tras la última reforma del Código Penal», cit., pp. 156 y 157, quien observa además que no existen tratamientos médicos eficaces para los psicópatas sexuales. 
trol, etc.). Desde esta perspectiva podría ser objeto de una valoración positiva pero sólo en referencia al grupo de delincuentes sexuales de riesgo elevado; de ahí la necesidad de que se proceda a solventar los apuntados problemas de su actual configuración legal.

El resurgimiento o mantenimiento, según el caso, de los principios orientadores de las medidas tras la imposición de la medida postpenitenciaria de libertad vigilada en la sentencia condenatoria se hace factible mediante la articulación de un procedimiento de revisión de esta medida en aras de decidir si se ratifica, porque persiste la peligrosidad criminal del sujeto manifestada en el delito cometido, y, consiguientemente, si se inicia su cumplimiento, o no. Sobre él versa el artículo 106.2, en virtud del cual básicamente el órgano sentenciador, a partir de la elevación por parte del juez de vigilancia penitenciaria de la oportuna propuesta, por el procedimiento del artículo 98, debe decidir bien la ratificación de la medida y su configuración en concreto, bien el cese de la misma (art. 106.3), su sustitución por otra o su suspensión en los términos del artículo 97. La propuesta del juez de vigilancia penitenciaria ha de realizarse al menos con dos meses de antelación a la extinción de la pena privativa de libertad en aras de que si se ratifica la medida ésta pueda comenzar a cumplirse seguidamente ${ }^{96}$.

Una vez que se ha concretado el contenido de la medida de libertad vigilada, el órgano sentenciador puede modificar en lo sucesivo las obligaciones y prohibiciones impuestas; reducir la duración de la libertad vigilada o incluso poner fin a la misma en vista del pronóstico positivo de reinserción que considere innecesaria o contraproducente la continuidad de las obligaciones o prohibiciones impuestas (art. 106.3). A estos efectos se apela al procedimiento señalado en el artículo 98.

Más allá de los problemas de legitimidad que en general suscita esta medida, su introducción reflejaría también una grave desconfianza por parte del legislador en la labor de los órganos de la Administración penitenciaria responsables de las decisiones relativas al régimen de vida de los penados y hacia los propios jueces de vigilancia penitenciaria.

96 En previsión de que la existencia de varias medidas de libertad vigilada pudiera conducir a la imposibilidad de un cumplimiento simultáneo de todas las obligaciones impuestas se establece en el artículo 106.2 que se cumplan de manera sucesiva, sin perjuicio de que el juez o tribunal pueda ejercer las facultades de modificar, reducir o dejarlas sin efecto. 


\section{La toma de muestras biológicas del condenado para la obtención de identificadores de ADN y su inscripción en la base de datos policial}

La aplicación de la biología molecular en la resolución mediante el análisis del ácido desoxirribonucleico de cuestiones con implicaciones jurídico penales no obtuvo reconocimiento legal en nuestro país hasta la reforma de la LECr. por la LO 15/2003. Reforma que se limitó a incidir en su uso en el campo de la investigación criminal para la identificación de la persona sospechosa de un concreto hecho; quedando, básicamente, el juez de instrucción facultado, en el caso de que mediasen acreditadas razones que lo justificasen, para autorizar la obtención de muestras biológicas del sospechoso que resultasen indispensables para la determinación de su perfil de ADN, a cuyo fin, y de acuerdo con los principios de proporcionalidad y razonabilidad, podría decidir la práctica de aquellos actos de inspección, reconocimiento o intervención corporal que resultasen adecuados (art. 363 p. 2) ${ }^{97}$. Habría que esperar algunos años más, no obstante, para que se aprobase una ley reguladora de la base de datos policial sobre identificadores obtenidos a partir del ADN.

La creación de esta base de datos policial por la LO 10/2007, de 8 de octubre, reguladora de la base de datos policial sobre identificadores obtenidos a partir del $\mathrm{ADN}^{98}$, persistía, sin embargo, por lo que refiere a sus funciones en el campo de la delincuencia ${ }^{99}$, en incorporar únicamente los datos exclusivamente reveladores de la identidad y del sexo de los sospechosos, detenidos e imputados por la comisión de delitos graves $\mathrm{y}$, en todo caso, por una serie de delitos entre los que se encuentran los delitos contra la indemnidad o la libertad sexual (arts. 3.1 a y 4$)^{100}$. Pero los identificadores a partir de entonces podrían utilizarse también en la investigación y averiguación de cualquier delito ${ }^{101}$.

97 Vid. también párrafo tercero del artículo 326 LECr.

98 Se recuerda en el Preámbulo de la ley que la creación de esta base de datos había sido recomendada por las instancias comunitarias. No se menciona, sin embargo, el más cercano en el tiempo y jurídicamente vinculante Convenio para la profundización de la cooperación transfronteriza, en particular en materia de lucha contra el terrorismo, la delincuencia transfronteriza y la migración ilegal, hecho en Prüm, de 27 de mayo de 2005, (BOE n ${ }^{\circ} .307$, de 25 de diciembre de 2006), en virtud del cual España asumió precisamente la obligación de crear y mantener ficheros nacionales de análisis del ADN para los fines de la persecución de los delitos sobre los que versa el tratado (art. 2.1).

${ }_{99}$ Esta base de datos responde a otras dos finalidades: la identificación de los restos cadavéricos y la averiguación de personas desaparecidas (art. 1).

100 El resto de delitos son: aquellos que afectan a la vida, a la libertad, a la integridad de las personas, al patrimonio si se comenten con fuerza en las cosas o con violencia o intimidación en las personas y los casos de delincuencia organizada; supuesto este último que engloba en todo caso los recogidos en el artículo 282 bis 4 LECr.

101 El artículo 9.1 de la ley dispone que esos datos se conservarán, en función del caso, durante el tiempo de prescripción del delito, el tiempo de cancelación de antecedentes 
Esta limitación de los potenciales afectados por la medida, unida a razones diversas, que explicarían porque no siempre es necesario ni se puede recoger identificadores obtenidos del ADN, ligadas algunas al respeto de los derechos individuales afectados por estas medidas (en especial, el derecho a la intimidad), suponía renunciar a una mayor eficacia en la prevención e investigación de futuros delitos ${ }^{102}$. Un objetivo que cobrará especial fuerza con la LO 1/2015 ${ }^{103}$.

Esta ley introduce entre las llamadas consecuencias accesorias del delito (Título VI del Libro I del CP) la toma de muestras biológicas del condenado para la obtención de identificadores de ADN y su inscripción en la base de datos policial. Según se puede leer en el Preámbulo de la ley (I y IX), la novedosa medida da respuesta a una obligación impuesta por el Convenio de Lanzarote. Se trataría exactamente del mandato previsto en su artículo 37.1, a cuyo tenor, "a efectos de la prevención y enjuiciamiento de los delitos tipificados con arreglo al presente Convenio, cada Parte adoptará las medidas legislativas o de otro tipo que sean necesarias para recoger y almacenar, de conformidad con las disposiciones aplicables sobre protección de datos de carácter personal y otras normas y garantías apropiadas que el derecho interno prevea, los datos relativos a la identidad y perfil genético (ADN) de las personas condenadas por los delitos tipificados con arreglo al presente Convenio" ${ }^{104}$. No obstante, como veremos, nuestro legislador cumple con esta obligación sólo parcialmente, pues ni la prevé con carácter imperativo ni la extiende a todos los delitos sexuales objeto del Convenio de Lanzarote, al tiempo que la medida abarca a otros delitos. Eso sí, la acota únicamente sobre quien ha sido condenado penalmente lo que supone la exclusión de la toma de muestras biológicas para la obtención de identificadores de ADN y su inscripción en la base de datos policial de los sujetos inimputables; quienes, paradójicamente, pueden verse sometidos a igual medida en el marco de la investigación de un delito, permaneciendo en ese caso sus identificadores obtenidos a partir del $\mathrm{ADN}$ en la base policial hasta que

penales y de las anotaciones de las medidas de seguridad, salvo resolución judicial en contrario. También se cancela la inscripción cuando adquiere firmeza el auto de sobreseimiento libre o la sentencia absolutoria por causa distinta a la inimputabilidad del sujeto.

102 Esto hacía que algunos autores abogaran por su ampliación. Así Gudín RodríguezMagariños, F., «La castración química para pedófilos: Un problema ético y penológico», en $A J A, 2007, \mathrm{n}^{\circ} .738$ (consulta web).

103 Vid. Valeije Álvarez, I., «La consecuencia accesoria de cesión de muestras biológicas y el registro de identificadores de ADN en las bases policiales (art. 129 bis del CP)", en Orts Berenguer, E./ Alonso Rimo, A./ Roig Torres, M., (dirs.), Peligrosidad criminal y Estado de Derecho, Ed. Tirant lo Blanch, Valencia, 2017, pp. 145-228.

104 Obsérvese que en el Informe explicativo del Convenio (§ 245) se insiste en que este artículo no impone a los Estados Parte la creación de una única base de datos, pudiendo estar esa información recogida en bases de datos separadas e incluso en bases que no sean específicas para delincuentes sexuales. 
cumplan la medida de seguridad o hasta su prescripción (art. 9. 1 LO 10/2007 y 137 CP).

Con carácter previo al análisis de nuestra concreta regulación de la cuestión, llevada a cabo en el artículo 129 bis del CP, es importante resaltar también que la inclusión de datos tan sensibles como los identificadores de $\mathrm{ADN}$ en una base de datos para su comparación con las muestras halladas en los escenarios delictivos comporta para las personas cuyos datos están registrados el sometimiento a la actividad probatoria de unos hechos delictivos sin necesidad de la concurrencia de un indicio que las incrimine. Esto supone siempre una afectación al derecho a la intimidad, del que forma parte el derecho a controlar los datos de naturaleza personal -autodeterminación informativa o habeas data- (art. 18.1 y $4 \mathrm{CE}$ ), y además pone en cuestionamiento el principio de presunción de inocencia. De ahí que, salvo que medie el consentimiento del titular de este derecho fundamental, la obtención de estos datos, su incorporación a una base de datos y su tratamiento deben realizarse al amparo de la existencia de un interés preponderante, de forma justificada y proporcionada. Consciente de estos problemas el legislador, en el Preámbulo de la LO 1/2015, afirma que la regulación de la cuestión se realiza de conformidad con las exigencias derivadas de la jurisprudencia del Tribunal Europeo de Derechos Humanos ${ }^{105}$.

A la luz del artículo 129 bis del CP la medida se fundamentaría en la existencia de un peligro relevante de reiteración delictiva por parte del sujeto condenado con los graves problemas que este tipo de juicio siempre encierran; lo que habría determinado que sean varios los autores que destaquen la proximidad de esta medida con las medidas de seguridad ${ }^{106}$. Siendo esto así, el hecho de que no conlleve en ningún caso un tratamiento correctivo, educativo o inocuizador, como sucede en puridad en las medidas de seguridad del Título IV de nuestro $\mathrm{CP}$, parece que no hace tan desaconsejable su previsión en ese cajón de sastre que conocemos como consecuencias accesorias del delito.

Ese peligro no se presupone en este caso por ley, lo que hace que la medida revista en su aplicación un carácter facultativo, pudiendo acordarla el juez o tribunal en relación sólo con los condenados a determina-

105 Valeije Álvarez, I., «La consecuencia accesoria de cesión de muestras biológicas y el registro de identificadores de ADN en las bases policiales (art. 129 bis del CP)», cit., pp. 184-197, nos acerca a la jurisprudencia del TEDH sobre la compatibilidad de la toma de muestras biológicas con el respeto a la vida privada (art. 8 del CEDH) y también a la doctrina del Tribunal Constitucional español, en especial a su sentencia n ${ }^{\circ}$. 199/2013, de 5 de diciembre.

106 Así Valeije Álvarez, I., «La consecuencia accesoria de cesión de muestras biológicas y el registro de identificadores de ADN en las bases policiales (art. 129 bis del CP)», cit., p. 204; Ramón Ribas, E., "Artículo 129 bis», en Quintero Olivares, G., (dir.), Comentarios al Código penal español, Tomo I (Artículos 1 a 233), $7^{\mathrm{a}}$. ed. Aranzadi, Navarra, 2015, pp. 890-891. 
dos delitos: delitos contra la vida, la integridad de las personas, ¿física, psíquica y/o moral?, la libertad, la libertad sexual o indemnidad, terrorismo y los delitos que conlleven un riesgo grave para la vida, la salud o la integridad física de la persona.

La forma de seleccionar estos delitos no ha estado exenta de críti$\mathrm{ca}^{107}$; siendo llamativa, desde el enfoque de estas líneas, que no se hayan tenido en cuenta en el precepto de forma expresa los delitos graves que implican un riesgo grave para la libertad e indemnidad sexual, como sucede en la trata de seres humanos con fines de explotación sexual (art. 177 bis). Todos estos delitos han de ser graves, esto es, tienen que estar castigados con una pena típica grave (arts. 13 y 33.2). A través de esta exigencia se pretendería establecer un criterio mínimo de gravedad en los hechos delictivos para aplicar esta medida, pero por el juego de las disposiciones relativas a la clasificación, en atención a su naturaleza y gravedad, de las penas (art. $33 \mathrm{CP}$ ) y la fijación de las penas principales en los distintos delitos, nos podemos encontrar con situaciones en las que la aplicación de esta medida finalmente resulte en hechos delictivos que revistan menor entidad ${ }^{108}$. Así, por ejemplo, vemos cómo el delito de abuso sexual del artículo 181.1, del que pueden ser víctimas menores de 16 y 17 años, tiene asociado una pena de prisión de uno a tres años o una multa de 18 a 24 meses, penas ambas menos graves, pero si lo comete el padre del menor deviene factible, por ejemplo, la aplicación de la pena de privación de la patria potestad o de la pena de inhabilitación especial para el ejercicio de los derechos de patria potestad de seis meses a seis años, penas ambas graves (art. 192.3); lo que provoca que estemos ya ante un delito grave.

El peligro de reiteración delictiva se inferiría así a partir de la naturaleza y gravedad del delito junto con las circunstancias del hecho, los antecedentes, la personalidad del sujeto y cualquier otra información disponible; parámetros señalados en el citado artículo. Ahora bien, no es suficiente con constatar la existencia de tal peligro, dado que la ley lo califica de relevante, lo que significa que ha de concurrir una alta probabilidad de reiteración delictiva ${ }^{109}$. Este matiz es especialmente interesante no sólo porque restringe la aplicación de una medida que afecta al derecho fundamental a la intimidad, sino también porque puede contrarrestar el efecto del juicio de pronóstico de peligrosidad criminal positivo

107 Valeije Álvarez, I., «La consecuencia accesoria de cesión de muestras biológicas y el registro de identificadores de ADN en las bases policiales (art. 129 bis del CP)», cit., pp. 211-214.

108 Apuntaba la necesidad de la reforma de la ley para los delitos graves y en particular para los violadores pero sólo de alto riesgo de reincidencia Mena, J. M., «¿Qué hacer con los agresores sexuales reincidentes?», cit., pp. 41-42.

${ }_{109}$ En este sentido Valeije Álvarez, I., "La consecuencia accesoria de cesión de muestras biológicas y el registro de identificadores de ADN en las bases policiales (art. 129 bis del CP)», cit., p. 218. 
que, como vimos, el propio legislador realiza iuris et de iure en relación con determinados delincuentes para fundamentar la imposición de una medida de libertad vigilada (art. 192.1 y art. 579 bis 2). Tampoco está claro el sentido de la expresión "reiteración delictiva"; si está referida a cualquier delito o a delitos de la misma naturaleza que aquel por el que el sujeto fue condenado. Esta última interpretación resultaría más coherente en consideración al enfoque de este tipo de medida: la prevención de concretos delitos.

Esta nueva consecuencia accesoria del delito requiere de la práctica de tres acciones, que se suceden en el tiempo: la toma de muestras biológicas del condenado (saliva, sangre, semen, células vaginales, pelo), la obtención de identificadores de ADN y la inscripción de éstos en la base de datos policial. Está previsto por ley que la primera de ella pueda realizarse de forma coactiva si el condenado no consiente; previéndose la adopción de medidas coactivas mínimas indispensable a tal fin, que han de ser proporcionadas a las circunstancias del caso y respetuosas con la dignidad humana. Una vez obtenida la muestra, el análisis de la misma sólo se puede realizar para obtener los identificadores que proporcionen exclusivamente información genética que revele la identidad de la persona y de su sexo. Será esta información la que será objeto de inscripción en la base de datos policial y además en el Registro Central de Delincuentes Sexuales -RCDS—, como indicaremos más adelante ${ }^{110}$.

\section{La restricción del ejercicio de profesiones o actividades que impliquen contacto habitual con menores}

El artículo 13.5 de la LO 1/1996, de 15 de enero, de protección jurídica del menor, tras su modificación por la Ley 26/2015, de 28 de julio, de modificación del sistema de protección a la infancia y a la adolescencia, recoge como requisito para el acceso y ejercicio a las profesiones, oficios y actividades que impliquen contacto habitual con menores, el no haber sido condenado en sentencia firme por algún delito contra la libertad e indemnidad sexual, incluyéndose expresamente en esta categoría las

110 En el marco de las consecuencias accesorias del delito nos encontramos con otra particularidad que afecta a los condenados por delitos relativos a la prostitución y a la explotación sexual y corrupción de menores y delitos de abusos y agresiones sexuales a menores de dieciséis años: el decomiso ampliado (art.127 bis). Asimismo en el artículo 189.8 se establece la adopción judicial de las medidas necesarias para la retirada de las páginas web o aplicaciones de internet que contengan o difundan pornografía infantil o en cuya elaboración hubieran sido utilizadas personas con discapacidad necesitadas de especial protección o, en su caso, el bloqueo del acceso a las mismas de los usuarios de internet que se encuentren en territorio español. Éstas también pueden aplicarse como medidas cautelares. 
agresiones y abusos sexuales, el acoso sexual, el exhibicionismo y la provocación sexual, la prostitución, explotación sexual y corrupción de menores, a los que se unen los delitos de trata de seres humanos. De esta forma se señala en el Preámbulo de la Ley que se cumplen los compromisos asumidos en el Convenio de Lanzarote y la Directiva 93/2011/ UE, si bien, además de las matizaciones que especialmente en relación con la previsión comunitaria ya se han realizado anteriormente, éstos concentrarían su ámbito de aplicación en determinados delitos y no en todos los delitos sexuales como hace la ley nacional ${ }^{111}$. Al mismo objetivo responde, y así se reconoce también en su Preámbulo, la previsión contenida en el artículo 8.4 de la Ley 45/2015, de 14 de octubre, del voluntariado, a cuyo tenor para tener la condición de voluntario en entidades de voluntariado o programas cuyo ejercicio conlleve el contacto habitual con menores es necesario no haber sido condenado por sentencia firme por delitos contra la libertad e indemnidad sexual, trata y explotación de menores ${ }^{112} 113$.

Nos encontramos ante un tipo de medida de naturaleza preventiva, controvertida por su efecto desocializador, su desconocida eficacia o el hecho mismo de convertir en sospechoso de abusador sexual de menores a cualquiera que pretenda desarrollarse profesionalmente o de forma altruista en ámbitos que implique ese contacto con menores ${ }^{114}$. La medida está enfocada en concreto a evitar la reiteración delictiva a partir de la reducción de la oportunidad para delinquir que pudiera implicar el hecho de estar en contacto habitual con menores; seguramente en con-

111 Aunque se silencie en motivos, este tipo de medida podríamos igualmente conectarla con el artículo 23.4 del Convenio del Consejo de Europa sobre la lucha contra la trata de seres humanos (Convenio ${ }^{\circ}$ 197), hecho en Varsovia el 16 de mayo de 2009, donde se prevé la prohibición del ejercicio de la actividad en el curso de la cual se cometió la infracción, de manera temporal o definitiva.

112 Hubiese sido más que deseable que el legislador armonizase el tipo de condena en ambas leyes, siguiendo preferiblemente la vía del artículo 13.5 por su mayor claridad. Esta falta de armonía se aprecia también en la referencia que se hace al registro que tiene que emitir la certificación sobre ese tipo de condenas. Se habla en esta ley del Registro Central de Penados (art. 8.4) y no del Registro Central de Delincuentes Sexuales, como hace el artículo 13.5 de la Ley 26/2015.

113 El descuido del legislador se observa en la propia ley con motivo de la extensión de la imposibilidad de ser voluntario a otros grupos de condenados. El artículo 8.5 señala que "tampoco podrán ser voluntarias las personas que tengan antecedentes penales no cancelados por delitos de violencia doméstica o de género, por atentar contra la vida, la integridad física, la libertad, la integridad moral o la libertad e indemnidad sexual del otro cónyuge o de los hijos, o por delitos de tráfico ilegal o inmigración clandestina de personas, o por delitos de terrorismo en programas cuyos destinatarios hayan sido o puedan ser víctimas de estos delitos"; afirmando en relación con todos ellos que esas situaciones se acreditarán mediante una declaración responsable de no tener antecedentes penales por estos delitos, a pesar de haber previsto anteriormente que el hecho de no haber sido condenado por delitos sexuales se acreditaría a través de la certificación registral.

114 Tamarit Sumalla, J. M., «La prueba de no ser pederasta: ¿una medida necesaria y proporcionada?», en AJA, 2016, n. 916, pp. 1-2. 
sideración a que un porcentaje importante de los delitos sexuales de los que son víctima los menores son cometidos por conocidos, si bien una parte de éstos tienen vínculos de parentesco con la víctima ${ }^{115}$. Esto no ha hecho, sin embargo, que el riesgo de reincidencia opere como condicionante de la limitación ${ }^{116}$, presumiéndose por la ley tal riesgo. Hay quien ha visto también en ella una protección de los menores frente a quien comete el delito sirviéndose del contexto de confianza que se genera en el desarrollo de algunas actividades profesionales o de voluntariado, aunque de la regulación legal de esta limitación de acceso y ejercicio a estos oficios, profesiones o actividad, está claro que la misma no se circunscribe a ese tipo de casos ${ }^{117}$.

La delimitación de las profesiones, oficios y actividades que impliquen contacto habitual con menores, al igual que sucedía en relación con la pena de inhabilitación especial para cualquier profesión u oficio, sea o no retribuido, que conlleve contacto regular y directo con menores de edad, debería realizarse a partir de una interpretación restrictiva de la norma que exija que aquellas conlleven por su naturaleza de forma innata un contacto habitual con los menores ${ }^{118}$. El problema, no obstante, en este caso se agudiza más porque a tenor del origen de la norma tal parece que finalmente la identificación de las mismas correspondería a los potenciales empleadores u organizadores de actividades (públicos o privados $)^{119}$, cuando en realidad el artículo 13.5 se habría limitado sen-

115 López, F/ Carpintero, E./ Hernández, A./ Martín, M.J./ Fuertes A., «Prevalencia y consecuencias del abuso sexual al menor en España», en Child Abuse \& Neglect, 1995, vol. $19, n^{\circ} .9$, p. 1046, precisan que principalmente se trataría de una persona conocida con la que la víctima no mantiene vínculo de parentesco; Pereda, N./ Forns, M., «Prevalencia y características del abuso sexual infantil en estudiantes universitarios españoles», en Child Abuse \& Neglect, 2007, n. 31, pp. 422-423; Benavente, B./ Casado, S./ Orte, C./ Ballester, L., Prevalencia del abuso sexual en la infancia. Un estudio en estudiantes universitarios, cit., pp. 52 y 56.

116 Críticamente Lledó Benito, I., «El artículo 13.5 de la Ley de protección jurídica del menor: certificado negativo de delitos de naturaleza sexual en profesiones y oficios con contacto habitual con menores de edad», en AA.VV. (dirs), Estudios jurídico penales y criminológicos. En homenaje al Prof. Dr. Dr. H. C. Mult. Lorenzo Morillas Cueva, Ed. Dykinson, Madrid, 2018, p. 2126.

117 Obsérvese que la persuasión y el engaño, sobre la base de la confianza, están muy presentes en la estrategia empleada por los abusadores sexuales de niños para cometer el delito sexual, según evidencia López Sánchez, F., Abusos sexuales a menores: lo que recuerdan de mayores, Ed. Ministerio de Asuntos Sociales, Madrid, 1994, pp. 98-99.

118 En este sentido la Agencia Española de Protección de Datos, quien tuvo ocasión de pronunciarse sobre la cuestión en su Informe 0401/2015, a raíz de una consulta planteada por una empresa cuya actividad económica consistía en la prestación de servicios de transporte público de viajeros por carretera y que contaba con numerosos trabajadores que en el desarrollo de su actividad estaban en contacto habitual con menores (conductores, azafatas, agentes de ventas, personal de estaciones de servicios, etc.), se refiere a que "la profesión en sí misma implique, por su propia naturaleza y esencia, un contacto habitual con menores".

119 Expresamente la Agencia Española de Protección de Datos en su Informe 0401/2015 señala que son los empresarios los que tiene que determinar qué puestos de 
cillamente a señalar que "quien pretenda el acceso a tales profesiones, oficios o actividades deberá acreditar esta circunstancia mediante la aportación de una certificación negativa del RCDS. A resultas de esta disposición un trabajador autónomo debería igualmente presentar tal certificación cuando solicita su alta en el registro especial de trabajadores autónomos para desarrollar una actividad que implique el contacto habitual con menores.

El hecho de que sea el empleador quien asuma la identificación de las actividades puede asimismo representar una merma de garantías para los ciudadanos. Especialmente en el ámbito de las actividades privadas y de voluntariado aquellos verán como los organizadores de éstas disponen de un poder decisivo sobre su desarrollo profesional o participación en voluntariado; y en todos los casos se abre la puerta a interpretaciones variadas sobre el significado de una expresión que, como dijimos, se delimitaría de forma más segura si se hubiera realizado un listado orientativo de naturaleza administrativa sobre las actividades afectadas ${ }^{120}$.

$\mathrm{Al}$ comparar esta medida con la pena mencionada, se observa rápidamente que queda abarcada claramente toda actividad que implique contacto habitual con menores, no siendo necesario, sin embargo, que el contacto sea directo ${ }^{121}$.

A los efectos de que este condicionante sea efectivamente observado, señala la ley que quien pretenda el acceso a tales profesiones, oficios o actividades deberá acreditar esta circunstancia mediante la aportación de una certificación negativa del RCDS. No se adentra, sin embargo, en la problemática concreta de quien accedió a la misma antes de que fuese obligatoria la presentación de esa certificación negativa o de aquel que estando ya vigente la actual regulación fue condenado por los delitos de referencia con posterioridad a que hubiese accedido al servicio ${ }^{122}$;

trabajo tienen un contacto directo, regular y habitual con menores.

${ }_{120}$ Distintos ejemplos recoge Lledó Benito, I., «El artículo 13.5 de la Ley de protección jurídica del menor: certificado negativo de delitos de naturaleza sexual en profesiones y oficios con contacto habitual con menores de edad», cit., pp. 2131-2141; sobre su implantación específicamente en los servicios públicos de salud, vid. Cabo Pérez, P./ Fernández Piedralba, E./ García Esteban, N., «El certificado negativo del registro central de delincuentes sexuales en el ámbito sanitario: normativa estatal y aplicación autonómica», en Derecho y Salud, 2017, vol. 27 Extr. XXVI, pp. 255-262, quienes denuncian la disparidad de criterios existentes sobre la aplicación del artículo 13.5. En este marco la Comisión de recursos humanos del sistema nacional de salud aprobó, el 26 de mayo de 2016, un acuerdo sobre criterios comunes para la aplicación del artículo 13.5 de la LOPJM.

121 La Agencia Española de Protección de Datos en su Informe 0401/2015 habla, sin embargo, de un contacto directo, regular y habitual con menores. También menciona el trato directo con el menor Lledó Benito, I., «El artículo 13.5 de la Ley de protección jurídica del menor: certificado negativo de delitos de naturaleza sexual en profesiones y oficios con contacto habitual con menores de edad», cit., p. 2134.

${ }_{122}$ Es posible que la normativa específica de algunas profesiones contemplen un sistema de revisión periódica de los requisitos normativamente exigidos para el desarrollo 
situaciones que pueden implicar la existencia de derechos laborales ya adquiridos. Tampoco en la consecuencia que se deriva para el trabajador del hecho de no disponer del correspondiente certificado, que habrá que buscar, dependiendo del caso concreto, en el Estatuto de los Trabajadores o en la legislación administrativa sobre el empleo en el ámbito de la función pública ${ }^{123}$.

Esta medida preventiva, que podría además ser efectiva en la disuasión del delincuente sexual para quien ese tipo de actividad es valiosa ${ }^{124}$, afecta a todas las personas, independientemente de su edad en el sentido de que todas tienen que aportar la certificación negativa del registro. No obstante, la auténtica restricción de derechos individuales la experimentan sólo las personas que han sido condenadas por los delitos mencionados. De ahí que se haya suscitado la duda sobre su naturaleza, planteándose si no estaríamos en realidad ante una sanción penal encubierta $^{125}$. Nosotros entendemos que no es así desde el momento en que es perfectamente legítimo que el desempeño de determinadas profesiones

de las mismas, así la Ley 44/2003, de 21 de noviembre, de ordenación de las profesiones sanitarias, señala un plazo mínimo de tres años (art. 8.3). Ahora bien el plazo de validez de la certificación negativa del RCDS es sólo de tres meses.

${ }^{123}$ Lledó Benito, I., "El artículo 13.5 de la Ley de protección jurídica del menor: certificado negativo de delitos de naturaleza sexual en profesiones y oficios con contacto habitual con menores de edad», cit., p. 2139, señala que las Administraciones públicas han optado por considerar que estamos ante una causa de despido objetivo por pérdida sobrevenida de capacidad para el desempeño de las funciones.

124 Sobre la importancia de la subjetividad en la disuasión del delito vid. Kennedy, D. M., Disuasión y prevención del delito. Reconsiderando la expectativa de pena, Ed. Marcial Pons, Madrid, 2016.

125 Salat Paisal, M., «Las consecuencias sancionadoras aplicables a los delincuentes sexuales tras las últimas reformas legislativas», cit., p. 36 considera que estamos ante una sanción de naturaleza penal, dado que su efecto sólo se dirige a quien comete delitos. Valeije Álvarez, I., «La consecuencia accesoria de cesión de muestras biológicas y el registro de identificadores de ADN en las bases policiales (art. 129 bis del CP)», cit., pp. 176-177, aunque no se refiere a ella como pena, destaca que ni respeta el principio de legalidad en materia de penas ni el artículo 25.2 CE, señalando que los derechos del condenado sólo se pueden ver limitados por la sentencia que le condenó, el sentido de la pena, o en caso de pena privativa de libertad por la LOGP. Lledó Benito, I., «El artículo 13.5 de la Ley de protección jurídica del menor: certificado negativo de delitos de naturaleza sexual en profesiones y oficios con contacto habitual con menores de edad», cit., p. 2123, estima que es una medida puramente administrativa que materialmente opera como una auténtica sanción penal porque su efecto sólo se dirige a quienes cometen el delito. También ha expresado sus dudas al respecto Molina Blázquez, M. C., «A propósito de la constitucionalidad del Real Decreto 1110/2015, que regula el registro de delincuentes sexuales», en $L P$, 2016 , n. 119 , p. 5, quien destaca que es una medida de inhabilitación. Fernández-Pacheco Estrada, C., "Medidas que afligen como penas. La inhabilitación para delincuentes sexuales para profesiones de contacto con menores», en $R P, 2019, \mathrm{n}^{\circ} .43, \mathrm{p} .53$, identifica su contenido con el de la inhabilitación especial prevista en el CP. Marco Francia, M. P., «La inscripción en el Registro de Delincuentes Sexuales, una pena de inhabilitación especial contraria al principio de legalidad. A propósito de la Sentencia núm. 37/2018 del Juzgado de lo Contencioso-Administrativo núm. 3 de Zaragoza», en $R J L, 2018$, nº. 9256, pp. 10, afirma que es una pena. 
o actividades esté condicionado al cumplimiento o posesión de determinados requisitos en aras de reducir riesgos graves para bienes jurídicos relevantes, como son en este caso la libertad e indemnidad sexual de los menores, aunque ello comporte, como sucede aquí, una restricción de derechos en cuanto a la libre elección de profesión u oficio (art. 35.1 CE), el acceso a funciones y cargos públicos (art. $23 \mathrm{CE}$ ) o la forma de disfrutar del tiempo de ocio (arts. 17.1 y 43.3 CE). De forma que la existencia de la condena penal es la prueba de la idoneidad del sujeto para desarrollar esa actividad pero no lo que determina su inidoneidad ${ }^{126}$. Ello no es óbice para considerar, sin embargo, que el legislador en parte ha errado en la ponderación de intereses en conflicto en la medida en que de forma automática ha dispuesto que toda condena por delitos sexuales ${ }^{127}$ y por el delito de trata de seres humanos — parece que en la ley del voluntariado se limita ésta a la trata de menores- ${ }^{128}$ produzca ese efecto desocializador, cuando de sobra es conocida la distinta gravedad de las conductas sexuales penalmente relevantes, por no mencionar la tendencia hacia la inflación de la criminalización de las conductas sexuales que se extiende tras la aprobación de la LO 10/1995, del CP, que ha dado lugar a algunos delitos sexuales cuestionables desde el principio de ofensividad de los

${ }^{126}$ He aquí la razón de que consideremos que no se conculca la prohibición de retroactividad de las normas restrictivas de derechos individuales. De otra opinión Valeije Álvarez, I., «La consecuencia accesoria de cesión de muestras biológicas y el registro de identificadores de ADN en las bases policiales (art. 129 bis del CP)», cit., p. 180.

127 Señala Lledó Benito, I., «El artículo 13.5 de la Ley de protección jurídica del menor: certificado negativo de delitos de naturaleza sexual en profesiones y oficios con contacto habitual con menores de edad», cit., p. 2123, que los delitos del artículo 183 ter no acceden al RCDS posiblemente porque les otorga autonomía respecto de los abusos y agresiones sexuales a menores; sin embargo, esta exclusión no es admisible pues, sin entrar en la discusión sobre ese particular, efectivamente están bajo ese enunciado legal en el CP, siendo precisamente la invocación de los distintos enunciados del título dedicado a los delitos contra la libertad e indemnidad sexual de menores la manera que ha elegido el artículo 13.5 para determinar el tipo de condena que fundamenta la limitación allí contenida.

${ }_{128}$ Algunos autores como Lledó Benito, I., «El artículo 13.5 de la Ley de protección jurídica del menor: certificado negativo de delitos de naturaleza sexual en profesiones y oficios con contacto habitual con menores de edad», cit., p. 2135, reinterpretan también el significado de la referencia a la condena por trata de seres humanos y consideran que tiene que ser aquella que tenía como finalidad la explotación sexual. Si bien esta tesis podría sustentarte en la finalidad de proteger a los menores en la esfera sexual, no debemos olvidar el ya citado Convenio de Varsovia que también pretende dispensar mayor protección frente a la trata. 
bienes jurídicos ${ }^{129}$, o la menor tasa de reincidencia específica de estos penados ${ }^{130}$.

Aunque la obligación que impone el artículo 13.5 es permanente, el efecto más gravoso que puede comportar no lo es dado que las inscripciones del RCDS, como veremos son cancelables. Ahora bien a tenor de su régimen de cancelación nos vamos a encontrar con que la descalificación que supone para el ejercicio de la profesión, oficio o actividad en cuestión resulta, si nos ceñimos a su duración, más gravosa que la pena correlativa. Obviamente por no ser una pena su incumplimiento no plantea la existencia de un delito de quebrantamiento de condena.

\section{EI Registro Central de Delincuentes Sexuales}

La administración de la justicia penal requiere a lo largo de sus distintas fases de la adopción de decisiones que en fuerte medida van a estar condicionadas por la información disponible sobre los investigados o justiciados. Esto hace que la creación de registros de datos referidos a las personas investigadas y penadas se haya considerado desde tiempo lejano de gran utilidad e incluso imprescindible para la aplicación de ciertas disposiciones procesales (especialmente las relativas a la adopción de medidas cautelares o el contraste de pruebas de ADN) y penales (muy en particular para la apreciación de la reincidencia, de la multireincidencia, de la condición de reo habitual, de la emisión de juicios de pronóstico sobre comportamiento criminal futuro, etc. ${ }^{131}$. Una utilidad que se ha acrecentado aún más como consecuencia de las facilidades del movimiento geográfico de las personas de un país a otro e incluso con las nuevas posibilidades delictivas favorecidas por las TIC, que requieren de una mayor cooperación policial y judicial entre los estados para reducir el delito. En contrapartida estos registros suponen ciertamente limitaciones en los derechos civiles de las personas, pudiendo ser éstas más o menos intensas dependiendo de la concreta configuración del registro; y obviamente de la ponderación de los fines y de los intereses en juego.

En un sistema de justicia penal como el nuestro en el que el hecho de haber sido condenado penalmente no significa que la persona penada deje de ser reconocido como titular de derechos y en el que se trata de

129 De ahí que algunos autores se hayan pronunciado en favor de limitar esta restricción a los condenados por delitos sexuales en perjuicio de menores. Así Lledó Benito, I., «El artículo 13.5 de la Ley de protección jurídica del menor: certificado negativo de delitos de naturaleza sexual en profesiones y oficios con contacto habitual con menores de edad», cit., p. 2140.

130 Vid. Tamarit Sumalla, J. M., La prueba de no ser pederasta: ¿una medida necesaria y proporcionada?, cit., pp. 1-2.

${ }_{131}$ El Real Decreto de 2 de octubre de 1878 dispuso por primera vez la creación en el Ministerio de Gracia y Justicia de un registro central de procesados y otro de penados. 
promover su reinserción social, los registros de esta naturaleza están muy enfocados en la actividad de los órganos judiciales y policiales y además se encuentran regidos por el principio de publicidad restringi$\mathrm{da}^{132}$. Lejos, por consiguiente, de los modelos registrales que al amparo de una cultura fuertemente defensora de la libertad de expresión y de la autodefensa se han ido implantando sin grandes objeciones en Estados Unidos desde mitad de la década de los noventa para determinados delincuentes, muy especialmente los delincuentes sexuales, pasando a formar parte de una estrategia de prevención de esta clase de delincuencia mediante la inocuización del delincuente sexual de la que se hace corresponsable a la propia sociedad ${ }^{133}$, que se han extendido también a otros países como Reino Unido ${ }^{134}$. No obstante lo dicho, la configuración de nuestro registro como un mecanismo al servicio de la prevención de la reiteración de delitos sexuales con víctimas menores se ha ido acentuado con el tiempo. Una primera muestra de lo dicho, la encontramos en la Decisión marco 2008/315/JAI del Consejo, de 26 de febrero de 2009, relativa a la organización y al contenido del intercambio de información de los registros de antecedentes penales entre los Estados miembros, cuyo considerando 12 señala que se pretende garantizar, entre otras cosas, que ningún condenado por delitos sexuales contra niños pueda ocultar en lo sucesivo la condena o la inhabilitación con el propósito de ejercer actividades profesionales relacionadas con la vigilancia de niños en otro Estado miembro de la UE, si su registro de antecedentes penales del Estado miembro de condena contiene dicha condena y si se ha impuesto y consta en el registro de antecedentes penales ${ }^{135}$. Al año siguiente, de forma apenas perceptible, se incorporó al Registro Central de Penados (RCP) y al Registro Central de Sentencias de Responsabilidad Penal de los Menores (RCSRPM) el dato relativo a la condición de menor de

132 Vid. Real Decreto 95/2009, de 6 de febrero, por el que se regula el sistema de registros administrativos de apoyo a la Administración de Justicia. Este reglamento se aplica supletoriamente al Real Decreto 1110/2015, de 11 de diciembre, por el que se regula el Registro Central de Delincuentes Sexuales (art. 2 de este último).

133 Ampliamente Alonso Rimo, A., «La publicidad de los antecedentes penales como estrategia de prevención del delito», en $R G D P, 2012$, n. 17; Fernández-Pacheco Estrada, C., "Registros de delincuentes sexuales y prevención del delito: análisis de la experiencia estadounidense», en EPC, 2014, n. 34, pp. 383-423.

134 Vid. Salat Paisal, M., "Las consecuencias sancionadoras aplicables a los delincuentes sexuales tras las últimas reformas legislativas», cit., pp. 312-315.

135 Se trataba de un objetivo que en particular había perseguido Bélgica, país en el que en el año 2003 había estallado el caso Fourniret, lo que le había llevado a presentar una propuesta de Decisión marco sobre reconocimiento mutuo de inhabilitaciones para trabajar con niños como consecuencia de condenas por delitos sexuales cometidos contra niños.

A tal fin la Decisión marco dispone que "la autoridad central del Estado miembro de condena comunicará cuanto antes a las autoridades centrales de los restantes Estados miembros las condenas pronunciadas dentro de su territorio contra los nacionales de los restantes Estados miembros, tal como figuren inscritas en el registro de antecedentes penales" (art. 4.2). 
edad de la víctima de los delitos contra la libertad e indemnidad sexual (art. 8.d del RD 95/2009, de 6 de febrero, por el que se regula el sistema de registros administrativos de apoyo a la Administración de Justicia) y finalmente en 2015 se creó un registro específico para delincuentes sexuales, el RCDS ${ }^{136}$.

La creación de este registro fue ordenada por la Ley 26/2015, de 28 de julio, de modificación del sistema de protección a la infancia y a la adolescencia, en atención al principio del interés superior del menor y con la mirada puesta en particular en la realización efectiva de las anteriormente citadas nuevas medidas de prevención de la violencia sexual contra menores enfocadas en la protección de las potenciales víctimas, en el favorecimiento de la investigación policial y en la cooperación judicial y policial supranacional en la erradicación del abuso y la explotación sexual de menores; pudiendo, no obstante, ser este registro en sí mismo considerado un mecanismo preventivo en atención a la información en él contenida y su aplicabilidad. De ahí que su utilidad como mecanismo preventivo se haya ceñido a la protección de menores, si bien el hecho de que la información en él contenida esté referida, como veremos, a todos los condenados por delitos sexuales y por el delito de trata de seres humanos con fines de explotación sexual le confiere un carácter más amplio.

De acuerdo con su disposición final decimoséptima ("Creación del registro central de delincuentes sexuales"), lo que se pedía exactamente al Gobierno era que organizase un registro central de delincuentes sexuales en los ya existentes RCP y RCSRPM, que se integrase igualmente en el sistema de registros de apoyo a la Administración de Justicia, y que se estableciera el régimen de inscripción y cancelación de sus asientos y el acceso a la información contenida en aquél, asegurando en todo caso su confidencialidad. En relación con la información que en el mismo se haría constar la ley señalaba únicamente que al menos se recogiesen los datos relativos a la identidad y perfil genético (ADN) de las personas condenadas por los delitos contra la libertad e indemnidad sexuales (en los que incluyen la agresión y abuso sexual, acoso sexual, exhibicionismo y provocación sexual, prostitución y explotación sexual y corrupción de menores) ${ }^{137}$. Prescripción que se conecta con el artículo 37.1 del Convenio de Lanzarote, relativo al registro y almacenamiento de datos nacionales sobre los delincuentes sexuales convictos, por el que los Estados parte estaban obligados a recoger y almacenar los datos relativos a la

136 Salat Paisal, M., «Las consecuencias sancionadoras aplicables a los delincuentes sexuales tras las últimas reformas legislativas», cit., p. 312, señala que dentro de la UE sólo tenían un registro específico de delincuentes sexuales Reino Unido (Sex Offenders Act de 1997), y Francia (Ley n ${ }^{\circ}$. 2004-204, de 9 de marzo, de reforma del Código de procedimiento penal).

137 Obsérvese que no se menciona el delito de trata de seres humanos. 
identidad y perfil genético (ADN) de las personas condenadas por los delitos tipificados con arreglo al mismo ${ }^{138}$. Fin para el cual podían adoptar cualquier medida necesaria, sin prejuzgar el convenio, ni ninguna otra norma supranacional, cual o cuales podrían ser éstas. Bastaría, a la luz del convenio, con que ese registro de datos se llevase a cabo de conformidad con las disposiciones aplicables sobre protección de datos de carácter personal y otras normas y garantías apropiadas de derecho interno.

La opción por la vía de la creación de un registro específico, por otra parte destacada en el considerando 43 de la Directiva 2011/93/UE ${ }^{139}$, se materializó efectivamente, dentro del plazo de seis meses marcado en la ley, con la aprobación del Real Decreto 1110/2015, de 11 de diciembre, por el que se regula el RCDS ${ }^{140}$, cuyo objetivo declarado en consonancia con la ley de referencia no era sino la creación y regulación de la organización y el funcionamiento del RCDS previsto en la Ley 26/2015, así como el régimen de inscripción, consulta, certificación y cancelación de los datos contenidos en aquél (art. 1.1). Ahora bien, en la ejecución de ese mandato no ha sido tan fiel como debiera a esa habilitación legal, resultando especialmente cuestionable que haya quebrantado la separación registral entre las condenas de adultos y las condenas de menores; separación que en su día se estableció precisamente en base a no obstaculizar la reinserción social de los menores en tanto interés superior del menor ${ }^{141}$. Este retroceso de la orientación reeducadora y de reinserción en el tratamiento de la delincuencia juvenil ha supuesto asimismo un cambio completo del criterio adoptado en la disposición adicional $3^{\text {a }}$ de la LO 5/2000, de 12 de enero, reguladora de la responsabilidad penal de

138 Recuérdese que la familia de los delitos sexuales tipificados en la legislación española es más amplia que aquella sobre la que incidía el Convenio de Lanzarote (art. 18 a 22).

139 "Los Estados miembros podrán considerar la adopción de medidas administrativas adicionales en relación con los delincuentes, tales como establecer la inscripción de personas condenadas por las infracciones contempladas en la presente Directiva en registros de delincuentes sexuales. El acceso a estos registros debe estar sujeto a limitaciones con arreglo a los principios constitucionales nacionales y las normas aplicables en materia de protección de datos, por ejemplo permitiendo el acceso solamente a las autoridades judiciales o a los cuerpos y fuerzas de seguridad".

La Resolución 1733 (2010), de 21 de mayo, de la Asamblea Parlamentaria del Consejo de Europa, de reforzamiento de las medidas contra los delincuentes sexuales, que asume el mito de que éstos se encuentran entre los delincuentes más reincidentes, contempla entre éstas la creación de tal registro pero con fines de intercambiar información entre las autoridades autorizadas, excluyéndose expresamente la posibilidad de un acceso al público en general, pero admitiéndose la facilitación de la información a cualquier persona si es necesario para proteger a un ,menor en particular $(16.2,5$ y 6).

140 Vid. Sobre el nuevo registro Salat Paisal, M., «El registro de delincuentes sexuales español: su regulación jurídica y su efecto en la prohibición para desempeñar profesiones que impliquen contacto habitual con menores», en $R G D P, 2016, \mathrm{n}^{\circ} .25$, pp. 1-15.

${ }_{141}$ También críticamente Salat Paisal, M., «El registro de delincuentes sexuales español: su regulación jurídica y su efecto en la prohibición para desempeñar profesiones que impliquen contacto habitual con menores», cit., p. 7. 
los menores ${ }^{142}$, a cuyo tenor los datos contenidos en el registro de sentencias firmes dictadas en aplicación de esta ley sólo podrán ser utilizados por los Jueces de Menores y por el Ministerio Fiscal a efectos de lo establecido en los artículos 6 (intervenciones del Ministerio Fiscal), 30 (proposición de medida) y 47 (refundición de medidas) de esta Ley, teniendo en cuenta lo dispuesto en la ley de protección de datos de carácter personal, y sus disposiciones complementarias. Sin olvidarnos, por otra parte, de que además nos encontramos en un terreno en el que la dispensación de una protección penal especialmente reforzada de la esfera sexual a los menores ha conducido a la criminalización de comportamientos que pueden ser en realidad manifestaciones del propio desarrollo de la sexualidad humana en la etapa de la adolescencia cuando menos inocuas y no abusos o explotación sexual que avalan interpretaciones restrictivas de las normas penales que no siempre son asumidas por los tribunales.

No es éste el único problema de carácter general que ha suscitado esta regulación reglamentaria. Algunos autores que han confrontado la misma con principios constitucionales como el principio de reserva de ley, el principio de proporcionalidad y el principio de irretroactividad de las leyes restrictivas de derechos individuales, cuestionan incluso su constitucionalidad $^{143}$.

A tenor de su concreta regulación reglamentaria el RCDS se nos presenta como un sistema de información, de carácter no público y gratuito, referido a personas condenadas en sentencia firme por cualquier delito contra la libertad e indemnidad sexual ${ }^{144}$, pero también por trata de seres humanos con fines de explotación sexual, incluida la pornografía ${ }^{145}$,

142 Esta disposición tiene naturaleza de ley ordinaria.

Para algunos autores el uso de estos "antecedentes penales" previstos por vía reglamentaria carecen de cobertura legal, así Valeije Álvarez, I., «La consecuencia accesoria de cesión de muestras biológicas y el registro de identificadores de ADN en las bases policiales (art. 129 bis del CP)», cit., p. 173, nota. 47.

${ }_{143} \mathrm{Al}$ respecto vid. Molina Blázquez, M. C., «A propósito de la constitucionalidad del Real Decreto 1110/2015, que regula el registro de delincuentes sexuales», cit., pp. 4-9; Valeije Álvarez, I., «La consecuencia accesoria de cesión de muestras biológicas y el registro de identificadores de ADN en las bases policiales (art. 129 bis del CP)», cit., pp. 177-180; Marco Francia, M. P., «La inscripción en el Registro de Delincuentes Sexuales, una pena de inhabilitación especial contraria al principio de legalidad. A propósito de la Sentencia núm. 37/2018 del Juzgado de lo Contencioso-Administrativo núm. 3 de Zaragoza», cit., pp. 10-12; Fernández-Pacheco Estrada, C., «Medidas que afligen como penas. La inhabilitación para delincuentes sexuales para profesiones de contacto con menores», cit., pp. 56-60.

144 Salat Paisal, M., «El registro de delincuentes sexuales español: su regulación jurídica y su efecto en la prohibición para desempeñar profesiones que impliquen contacto habitual con menores», cit., p. 8 , se muestra muy crítico al considerar que estos delitos son de muy distinta gravedad, apelando a que se exija que además exista un riesgo de comisión de futuros delitos de la misma naturaleza.

${ }_{145}$ Críticamente Salat Paisal, M., «El registro de delincuentes sexuales español: su regulación jurídica y su efecto en la prohibición para desempeñar profesiones que impliquen contacto habitual con menores», p. 7, quien considera que no hay habilitación legal 
e independientemente de la edad de la víctima, relativo a la identidad, al perfil genético — código identificador del perfil genético (ADN)—, a las penas y a las medidas de seguridad impuestas (art. 3.1) ${ }^{146}$.

Un conocimiento más preciso de la información que ha de registrarse se obtiene a partir del artículo 5.1 del reglamento en el que se dispone que el RCDS contendrá toda la información penal que conste tanto en el RCP como en el RCSRPM respecto de quienes hubieran sido condenados en sentencia firme por cualquier delito de referencia, en los términos previstos en los artículos 8 y 9 del Real Decreto 95/2009, de 6 de febrero, salvo los datos de identidad de la víctima ${ }^{147}$, con excepción, en su caso, de su condición de menor de edad. En el primero de los artículos mencionados se recoge información de carácter general y en el segundo información contenida en la inscripción de sentencias firmes que condenan a personas adultas; quedando, por tanto, excluida la transmisión de información sobre los datos contenidos en las sentencias firmes recogidas en el RCSRPM (art. 11) ${ }^{148}$. A resultas de lo dicho, la información obrante en el RCDS sería la siguiente: en primer lugar, los datos identificativos de la persona registrada ${ }^{149}$, que tratándose de una persona física son el nombre y apellidos del condenado, rebelde, sometido a medidas de seguridad o medida cautelar, alias en su caso, sexo, fecha de nacimiento, nombre de los padres, localidad, provincia, país de nacimiento, domicilio conocido, nacionalidad y documento nacional de identidad o NIE, pasaporte o tarjeta de identidad en el caso de los extranjeros, número ordinal informático policial y número de atestado. En segundo lugar, los datos de orden judicial concernientes al órgano judicial que acuerda la resolución, la fecha de la misma, la clase y número de procedimiento y el

alguna para incluir la trata de seres humanos con fines de explotación sexual así como los delitos de embaucamiento y el online child grooming. Al que sigue Lledó Benito, I., «El artículo 13.5 de la Ley de protección jurídica del menor: certificado negativo de delitos de naturaleza sexual en profesiones y oficios con contacto habitual con menores de edad», cit., p. 2123. En mi opinión los delitos sexuales del artículo 183 ter se conocen también como modalidades de abuso sexual y, por tanto, el problema no sería tal.

146 Obsérvese que nuestro sistema penal también contempla medidas de seguridad para personas exentas de responsabilidad penal.

147 En relación con las víctimas en los otros registros se hace constar sus datos personales identificativos, su domicilio o domicilios conocidos, la relación de parentesco entre la víctima y el condenado o denunciado siempre que sea necesario y, en todo caso, en los procedimientos de violencia doméstica o de género.

148 Tampoco se transmite la información contenida en la inscripción de medidas cautelares, requisitorias, autos de rebeldía o sentencias no firmes (art. 10).

${ }^{149}$ Si fuese una persona jurídica, quien puede, como ya se apuntó, ser responsable penalmente de algunos de los delitos que citamos, se hará constar la razón o denominación social, nacionalidad, domicilio social y domicilio fiscal, actividad principal, tipo de sociedad, número o código de identificación fiscal y datos registrales. Esa remisión genérica hace asimismo que también se haya de contemplar en el RCDS información sobre los entes sin personalidad jurídica que hubiesen sido condenados en esos concretos contextos; en este caso se hará constar denominación, número o código de identificación fiscal o cualquier otro dato que sirva para su identificación. 
número de identificación general. En tercer lugar, la condición de menor de edad de la víctima. Un dato que consta en los otros registros sólo si se trata de un delito contra la libertad e indemnidad sexual; lo que provoca que el responsable del RCDS tenga que adoptar otras medidas para recibir esa información. En cuarto lugar, en el caso de sentencias firmes que impongan penas o medidas de seguridad a personas físicas mayores de edad se hace constar la fecha de la sentencia que imponga la pena o medida de seguridad; la fecha de firmeza de la sentencia y fecha de efectos del requerimiento del cumplimiento; el órgano judicial sentenciador; la condición de reincidente y/o reo habitual del condenado en su caso; el órgano judicial de ejecución de la sentencia, en su caso; el número y año de la ejecutoria; el delito o delitos y precepto penal aplicado; la pena o penas principales y accesorias, medida de seguridad y su duración y cuantía de la multa con referencia a su duración y cuota diaria o multa proporcional; la fecha de comisión del delito; la participación como autor o cómplice y grado de ejecución; la sustitución de las penas o medidas de seguridad, en su caso; la suspensión de la ejecución de las penas o medidas de seguridad, en su caso, fecha de notificación, así como plazo por el que se concede la suspensión; la prórroga del auto de suspensión de las penas; la fecha de la revocación del auto de suspensión de las penas o medidas de seguridad; la fecha de la remisión definitiva de la pena, de cumplimiento efectivo de la misma o de prescripción; la fecha del cese de la medida de seguridad; la expulsión y fecha de la misma, cuando se acuerde como sustitución de la pena o medida de seguridad; el cumplimiento; la acumulación de penas; y la responsabilidad civil derivada de la infracción penal ${ }^{150}$.

En este orden de cosas lo que hace en este punto el RCDS es dar un tratamiento conjunto a toda esta información, que se amplía con la referencia a la condición de menor de la víctima del delito de trata de seres humanos con fines de explotación sexual y, si así se ha acordado por el órgano judicial ${ }^{151}$, con el código identificador del perfil genético (ADN) del condenado ${ }^{152}$; muy posiblemente logrando con ello mejorar la colaboración entre la Administración General del Estado con las autoridades competentes de los Estados miembros de la UE en lo que se refiere a la facilitación del intercambio de información.

150 En el caso de las personas jurídicas también las resoluciones judiciales que se pronuncien sobre el traslado de la pena (art. 130.2 CP).

151 Obsérvese que aunque el reglamento en su artículo 3.1. menciona genéricamente el código identificador del perfil genético, la ley y el artículo 129 bis del CP exigen autorización judicial para incluir tal dato en la base de datos policial, de ahí la ulterior precisión del artículo 5.1.

${ }^{152}$ A tal fin, su artículo 8.2 dispone que "el Ministerio de Justicia habilitará a los funcionarios autorizados encargados de la Base de Datos Nacional de ADN del Ministerio del Interior para que puedan incorporar el código identificador del perfil genético". 
Toda esta información está destinada a usarse, como anticipábamos, en la lucha contra la explotación y el abuso sexual de menores de forma preventiva, permitiendo, de un lado, conocer la existencia o no de condenas penales por los delitos mencionados en aras de impedir que quienes han sido condenados por los mismos puedan acceder y ejercer profesiones, oficios y actividades que impliquen el contacto habitual con menores; y facilitando, de otro lado, la investigación y persecución de esos delitos mediante la introducción de medidas eficaces para la identificación de los autores de los delitos y para la cooperación judicial y policial internacional, particularmente con los Estados miembros de la UE y del Consejo de Europa, (art. 3.2). Precisamente por la importancia de la cooperación entre estados para erradicar el fenómeno de la explotación sexual de menores, la información se refiere tanto a las condenas dictadas tanto en España como en otros países, en particular los Estados miembros de la UE y del Consejo de Europa (art. 3.1) ${ }^{153}$.

Como decíamos, el RCDS no es un registro público, debiendo el Ministerio de Justicia autorizar el acceso directo a los datos allí contenidos sólo a un grupo reducido de funcionarios y siempre al objeto de cumplir los fines y objetivos del registro (art. 8.1). Concretamente tienen acceso directo los jueces y tribunales de cualquier orden jurisdiccional ${ }^{154}$, el Ministerio Fiscal ${ }^{155}$ y la policía judicial ${ }^{156}$.

Pero la información registrada se puede facilitar también por parte del encargado del registro a un grupo limitado de terceros en los términos previstos en el artículo $9^{157}$. Así a los efectos de impedir el acceso y

153 De conformidad con el artículo 10.2 la cancelación de las inscripciones derivadas de sentencias dictadas por Jueces o Tribunales extranjeros que consten en el RCDS, exigirá la previa comunicación en tal sentido por parte del Estado de condena.

${ }^{154}$ En este caso lo hacen a través del personal de cada órgano u oficina judicial autorizado por el Letrado de la Administración de Justicia. Pueden acceder a todos los datos, incluidos los datos de las inscripciones canceladas y el motivo del acceso tiene que ser su utilización en los procedimientos y actuaciones de los que estén conociendo en el ámbito de sus respectivas competencias.

Nótese también que los jueces y tribunales, en relación con las causas que tramiten y para su unión al procedimiento, pueden obtener directamente los datos contenidos en el registro y aportarlos al procedimiento judicial mediante diligencia de constancia del Letrado de la Administración de Justicia, con plena validez jurídica, sin necesidad de solicitar certificación al responsable del registro (art. 9.1).

155 Éstos acceden a través del personal de cada órgano u oficina fiscal autorizado por el Fiscal Jefe, cuando ello resulte necesario para el cumplimiento de sus funciones legalmente atribuidas.

156 El acceso se produce a través de los funcionarios autorizados que desempeñen estas funciones, en tanto sea necesario para el ejercicio de las competencias previstas en el artículo 549. 1 de la LOPJ, en relación con la prevención, persecución y seguimiento de las conductas inscritas en este registro.

157 Entre ellos, y en aras de valorar la situación de desamparo de un menor, se encuentran las entidades públicas de protección de menores competentes territorialmente, quienes pueden solicitar los datos que resulten necesarios de su progenitor, tutor, guardador 
ejercicio de profesiones, oficios o actividades que impliquen un contacto habitual con menores se regula un sistema de certificaciones del que es responsable el encargado del registro. Éstas pueden ser solicitadas bien por parte de cualquier órgano de las Administraciones Públicas ante el que se tramite un procedimiento a tal fin, supuesto en el que el encargado del registro informará de los datos relativos al mismo, siempre que no se trate de información reservada a Jueces y Tribunales, y previo consentimiento del interesado o de su representante, (art. 9.2); bien por parte del titular interesado, situación en la que el encargado del registro podrá certificar directamente los datos relativos al solicitante ${ }^{158}$ y suscribir certificaciones negativas respecto a personas que no figuren inscritas ${ }^{159}$. En el caso de titulares interesados menores de edad o personas con la capacidad modificada judicialmente la solicitud habrá de ser efectuada, en todo caso, por su representante legal (art. 9.3). Esta misma disposición establece que en todo caso, los ciudadanos de origen extranjero o que tuvieran otra nacionalidad, deberán, además, aportar certificación negativa de condenas penales expedido por las autoridades de su país de origen o de donde sean nacionales.

En el marco de una investigación judicial o policial, o de prevención del delito, las autoridades judiciales o policiales extranjeras que lo requieran también podrán solicitar al encargado del Registro la información que allí consta, estando éste obligado a transmitirla, sin el consentimiento del interesado, en las formas y supuestos que determinen las normas comunitarias y los tratados internacionales de asistencia judicial en materia penal suscritos por España.

El régimen de cancelación de las inscripciones corre paralelo al de la cancelación de los antecedentes delictivos a excepción de algunas particularidades presentes para el caso del condenado mayor de edad y víctima menor de edad y de los autores menores de edad ${ }^{160}$. En el primer supuesto, especialmente controvertido por lo que supone para la reinserción social de los condenados ${ }^{161}$, la cancelación de la inscripción no tiene lugar hasta el transcurso de un plazo de treinta años sin delinquir

o acogedor, aún sin consentimiento y siempre que no se trate de información reservada a jueces y tribunales (art. 9.4).

${ }_{158}$ La certificación positiva contendrá la transcripción de los datos inscritos, tal y como obren en el registro en el momento de su expedición, excluyendo las inscripciones que, conforme a una norma con rango de ley, se hallen a disposición exclusiva de jueces y tribunales (art. 9.3).

159 En la práctica se ha habilitado la posibilidad de que el empleado autorice a la empresa para que efectúe una solicitud agrupada de todos sus empleados.

160 Vid. artículo 19 del RD 95/2009, que dispone que la cancelación en el caso de autor y víctima adultos se produce tras el cumplimiento de los requisitos para la cancelación de los antecedentes penales (art. 136).

${ }_{161}$ Críticamente Valeije Álvarez, I., «La consecuencia accesoria de cesión de muestras biológicas y el registro de identificadores de ADN en las bases policiales (art. 129 bis del $\mathrm{CP}) »$, cit., pp. 174-175, señala que no es razonable ni proporcionado, ni preserva el prin- 
- dos tercios más del tiempo que implicaría la cancelación de antecedentes penales en caso de haber sido condenado a una pena grave- (art. 10.1.b) ${ }^{162}$. Ahora bien esta inscripción no tiene efectos en materia de reincidencia una vez que haya transcurrido el plazo previsto en el CP para la cancelación de los antecedentes penales ${ }^{163}$. En el segundo caso, el plazo es siempre de diez años a partir del momento en que se adquiere la mayoría de edad y siempre que las medidas hubiesen sido ejecutadas de forma completa o prescrito (art. 10.1 a en relación con el artículo 24 del Real Decreto 95/2009, de 6 de febrero, por el que se regula el sistema de registros administrativos de apoyo a la Administración de Justicia).

Estos plazos únicos, también cuestionables por su desconexión de la gravedad del hecho o del pronóstico de peligrosidad criminal del sujeto ${ }^{164}$, se computan desde el día en que se considere cumplida la pena de conformidad con el artículo 136 del Código Penal sin haber vuelto el penado a delinquir ${ }^{165}$.

\section{Bibliografía}

Alonso Rimo, A., «La publicidad de los antecedentes penales como estrategia de prevención del delito», en $R G D P, 2012, \mathrm{n}^{\circ} .17$.

Álvarez García, F. J., (dir.), Estudio crítico sobre el anteproyecto de reforma penal de 2012, Ed. Tirant lo Blanch, Valencia, 2013.

Armaza Armaza, E. J., El tratamiento penal del delincuente imputable peligroso, Ed. Comares, Granada, 2013.

Benavente, B./ Casado, S./ Orte, C./ Ballester, L., Prevalencia del abuso sexual en la infancia. Un estudio en estudiantes universitarios, Ed. Octaedro, Barcelona, 2016.

cipio de reeducación y reinserción social ni los límites de la potestad sancionadora del estado, recordando el derecho penal de autor.

162 Recuérdese que el Informe explicativo del Convenio de Lanzarote (§ 57) incidía en el hecho de que éste no persigue interferir en las legislaciones nacionales sobre la cancelación de los antecedentes penales.

${ }^{163}$ La cancelación de los antecedentes penales de los inscritos en el RCDS y respecto de aquellas causas en las que constara el código identificador del perfil genético del condenado, implica que el encargado del registro tenga que comunicar la misma a la Base de Datos Nacional de ADN del Ministerio del Interior, a los efectos previstos en el artículo 9 de la LO 10/2007, (art. 10.3).

${ }_{164}$ Por lo que se refiere a la prohibición de exceso en relación con la gravedad del hecho Fernández-Pacheco Estrada, C., «Medidas que afligen como penas. La inhabilitación para delincuentes sexuales para profesiones de contacto con menores», cit., p. 51.

165 Esta expresión resulta confusa, dado que ese artículo no está referido a cuándo se considera cumplida la pena sino al día de inicio del cómputo del plazo para la extinción de los antecedentes penales, que es realmente lo interesante aquí y a lo que seguramente quería referirse el reglamento. 
Benítez ORTúZAR, I. F., «La nueva "medida de seguridad" de "libertad vigilada" aplicable al sujeto imputable tras el cumplimiento de la pena privativa de libertad. La admisión de los postulados del "Derecho penal del enemigo" por la LO5/2010», en CPC, 2011, nº 103.

Boldova Pasamar, M. A., «Penas privativas de derechos», en Gracia Martín, L., (coord.), Lecciones de consecuencias jurídicas del delito, $4^{\mathrm{a}}$ ed. Tirant lo Blanch, Valencia, 2012 (última edición, 5ª 2015).

BORJA JimÉNEZ, E., "Custodia de seguridad, peligrosidad postcondena y libertad en el estado democrático de la era de la globalización: una cuestión de límites», en RGDP, 2012, $\mathrm{n}^{\circ} .18$.

CABo Pérez, P./ Fernández Piedralba, E./ García Esteban, N., «El certificado negativo del registro central de delincuentes sexuales en el ámbito sanitario: normativa estatal y aplicación autonómica», en Derecho y Salud, 2017, vol. 27 Extr. XXVI.

Cano Paños, M. A., «El marco jurídico y criminológico de la custodia de seguridad (Sicherungsverwahrung) en el Derecho penal alemán», en CPC, 2007, $\mathrm{n}^{\circ} .91$.

CANTÓN-Cortés, D./ Cortés, M. R., «Consecuencias del abuso sexual infantil: una revisión de las variables intervinientes», en Anales de Psicología, 2015, vol. 31, $\mathrm{n}^{\circ} .2$.

Castillo Martínez, C. del C., La privación de la patria potestad. Criterios legales, doctrinales y judiciales, $2^{\mathrm{a}} \mathrm{ed}$. La Ley, Madrid, 2010.

FERNÁndeZ-Pacheco Estrada, C., «Medidas que afligen como penas. La inhabilitación para delincuentes sexuales para profesiones de contacto con menores», en $R P, 2019, \mathrm{n}^{\circ} .43$.

- «Registros de delincuentes sexuales y prevención del delito: análisis de la experiencia estadounidense», en EPC, 2014, $\mathrm{n}^{\circ} .34$

FloRES RodRíguez, J., «La privación de la patria potestad en los delitos sexuales contra menores», en $L P, 2012, \mathrm{n}^{\circ} .90$.

Gil GiL, A./ Lacruz LóPez, J. M./ Melendo Pardos, M./ NúÑez Fernández, J., Consecuencias jurídicas del delito. Regulación y datos de la respuesta a la infracción penal en España, Ed. Dykinson, Madrid, 2018.

GonZÁlez TASCón, M. M., «El mecanismo de respuesta penal frente al delincuente sexual imputable: del favorecimiento de la ideología inocuizadora en detrimento del tratamiento resocializador», en Roca Agapito, L. (dir.), Un sistema de sanciones penales para el siglo XXI, Ed. Tirant Lo Blanch, Valencia, 2019.

— «Nuevas obligaciones para España en la lucha contra la explotación sexual de los menores y la pornografía infantil: la Directiva 2011/92/ $\mathrm{UE} »$, en $R P, 2012, \mathrm{n}^{\circ} .30$. 
- «La protección penal de los menores en la esfera sexual a la luz del Convenio del Consejo de Europa para la protección de los niños contra la explotación y el abuso sexual», en RDPCrUNED, 2012, $\mathrm{n}^{\circ} .8$.

Guinarte CABADA, G., «La pena de inhabilitación especial de los derechos de patria potestad, tutela, guarda o curatela», en Faraldo Cabalda, P./ Puente Aba, L. M., (dirs.), Las penas privativas de derechos y otras alternativas a la privación de libertad, Ed. Tirant lo Blanch, Valencia, 2013.

Gudín RodRíguEZ-MAGaRIÑos, F., «La castración química para pedófilos: Un problema ético y penológico», en $A J A, 2007, \mathrm{n}^{\circ} .738$.

Gutiérrez Castañeda, A., "Penas privativas y restrictivas de derechos», en Roca Agapito, L. de, Las consecuencias jurídicas del delito, Ed. Tirant lo Blanch, Valencia, 2016.

JACoBS, J. B./ BlitsA, D., «Paedophiles, employment discrimination, and European integration», en New York University Public Law and Legal Theory Working Papers, 2011, nº 309.

Kennedy, D. M., Disuasión y prevención del delito. Reconsiderando la expectativa de pena, Ed. Marcial Pons, Madrid, 2016.

LóPez SÁnchez, F., Abusos sexuales a menores: lo que recuerdan de mayores, Ed. Ministerio de Asuntos Sociales, Madrid, 1994.

López, F./ Carpintero, E./ Hernández, A./ Martín, M.J./ Fuertes A., «Prevalencia y consecuencias del abuso sexual al menor en España», en Child Abuse \& Neglect, 1995, vol. 19, n. 9.

Lledó Benito, I., «El artículo 13.5 de la Ley de protección jurídica del menor: certificado negativo de delitos de naturaleza sexual en profesiones y oficios con contacto habitual con menores de edad», en AA.VV. (dirs), Estudios jurídico penales y criminológicos. En homenaje al Prof. Dr. Dr. H. C. Mult. Lorenzo Morillas Cueva, Ed. Dykinson, Madrid, 2018.

Magro Servet, V. «La prohibición del uso de las redes sociales como pena en los delitos cometidos por internet», en RJL, 2019, nº 9449.

Manzanares Samaniego, J. L., «La pena de interdicción civil», en ADPCP, 1979, Tomo 32, Fasc/Mes 2.

Marco Francia, M. P., «La inscripción en el Registro de Delincuentes Sexuales, una pena de inhabilitación especial contraria al principio de legalidad. A propósito de la Sentencia núm. 37/2018 del Juzgado de lo Contencioso-Administrativo núm. 3 de Zaragoza», en RJL, 2018, $\mathrm{n}^{\mathrm{o}} .9256$.

- Los agresores sexuales de menores: aspectos criminológicos y tratamiento jurídico penal, 2015. Tesis doctoral disponible en https://ruidera.uclm.es/xmlui/bitstream/handle/10578/7171/TESIS\%20Marco\%20 Francia.pdf?sequence=1 (consulta 24-05-2017). 
Mena, J. M., «¿Qué hacer con los agresores sexuales reincidentes?», en ¿Qué hacer con los delincuentes sexuales reincidentes?, Ed. Fundación Víctor Grífols i Lucas, 2009.

Messía de la Cerda Ballesteros, J. A., «La privación de la patria potestad por sentencia penal», en La Ley Derecho de Familia: Revista Jurídica sobre Familia y Menores, 2016, $\mathrm{n}^{\circ} .12$.

Molina Blázouez, M. C., «A propósito de la constitucionalidad del Real Decreto 1110/2015, que regula el registro de delincuentes sexuales», en $L P, 2016, \mathrm{n}^{\circ} .119$.

NAVARRo Frías, I., «Psicopatía y medidas de seguridad: el caso de los psicópatas sexuales y la libertad vigilada tras la última reforma del Código Penal», en CPC, 2011, nº 105.

Pereda, N./ Forns, M., «Prevalencia y características del abuso sexual infantil en estudiantes universitarios españoles», en Child Abuse \& Neglect, 2007, n'. 31 .

Quintero Olivares, G., "Las penas en el siglo XXI, reflexiones obligatorias», en Roca Agapito, L., (dir.), Un sistema de sanciones penales para el siglo XXI, Ed. Tirant lo Blanch, Valencia, 2019.

Ramón Ribas, E., «Artículo 129 bis», en Quintero Olivares, G., (dir.), Comentarios al Código penal español, Tomo I (Artículos 1 a 233), $7^{\mathrm{a}}$. ed. Aranzadi, Navarra, 2015.

Rey Huidobro, L. F., «La pena de inhabilitación especial para el ejercicio de la patria potestad, tutela, curatela, guarda o acogimiento», en $R J L$, 2004, n'. 6007.

Ruisánchez CAPElástegui, C., «Privación de la patria potestad y proceso penal. Comentario a la STS, $2^{\mathrm{a}}, 28.4 .2006 »$, en Indret, 2007, $\mathrm{n}^{\circ} .4$.

- «Nota sobre la privación de la patria potestad en el anteproyecto de modificación del Código Penal», en Indret, 2009, nº 2.

Salat Paisal, M., "Sanciones penales en los delitos sexuales contra menores», Tamarit Sumalla, J. M., (coord.), La victimización sexual de menores de edad y la respuesta del sistema de justicia penal, Ed. Edisofer, Madrid, 2017.

— «El registro de delincuentes sexuales español: su regulación jurídica y su efecto en la prohibición para desempeñar profesiones que impliquen contacto habitual con menores», en RGDP, 2016, $\mathrm{n}^{\circ} .25$.

- «Las consecuencias sancionadoras aplicables a los delincuentes sexuales tras las últimas reformas legislativas», en EPC, 2016, vol. XXXVI.

SANZ MoRán, A. J., «La nueva medida de libertad vigilada: reflexión político-criminal», en Muñoz Conde, F./ Lorenzo Salgado, J. M./ Ferré Olivé, J. C./ Cortés Bechiarelli, E./ Núñez Paz, M. A., (dir.), Un Dere- 
cho penal comprometido: libro homenaje al Prof. Dr. Gerardo Landrove Díaz, Ed. Tirant lo Blanch, Valencia, 2011.

Souto García, E. M., «La pena de privación de la patria potestad», en Faraldo Cabalda, P./ Puente Aba, L. M., (dirs.), Las penas privativas de derechos y otras alternativas a la privación de libertad, Ed. Tirant lo Blanch, Valencia, 2013.

TAmarit Sumalla, J. M., «La prueba de no ser pederasta: ¿una medida necesaria y proporcionada?», en $A J A, 2016, \mathrm{n}^{\circ} .916$.

- «Sección $3^{\mathrm{a}}$. De las penas privativas de derechos», en Quintero Olivares, G., (dir.), Comentarios al Código penal español. Tomo I (Artículos 1 a 233), Ed. Aranzadi, Navarra, 2016.

Tamarit, J. M./ Guardiola Lago, M. J./ Hernández-Hidalgo, P./ PadróSolanet, A., «Estudio de sentencias: decisiones judiciales en los casos de victmización sexual de menores», en Tamarit Sumalla, J. M., (coord.), La victimización sexual de menores de edad y la respuesta del sistema de justicia penal, Ed. Edisofer, Madrid, 2017.

- «La victimización sexual de menores de edad: un estudio de sentencias», en REIC, 2014, nº 19.

Valeije Álvarez, I., «La consecuencia accesoria de cesión de muestras biológicas y el registro de identificadores de ADN en las bases policiales (art. 129 bis del CP)», en Orts Berenguer, E./ Alonso Rimo, A./ Roig Torres, M., (dirs.), Peligrosidad criminal y Estado de Derecho, Ed. Tirant lo Blanch, Valencia, 2017.

Villacampa Estiarte, C., «Penas accesorias», en Álvarez García, F. J./ González Cussac, J. L., (dirs.), Comentarios a la reforma penal de 2010, Ed. Tirant lo Blanch, Valencia, 2010.

Zugaldía EsPinar, J. M., «Medidas de seguridad complementarias y acumulativas para autores peligrosos tras el cumplimiento de la pena», en RDPCrUNED, 2009, $\mathrm{n}^{\circ} .1$. 